Review

\title{
Bioethanol a Microbial Biofuel Metabolite; New Insights of Yeasts Metabolic Engineering
}

\author{
Khaled A. Selim ${ }^{1, *}$, Dina E. El-Ghwas ${ }^{1,2}$, Saadia M. Easa ${ }^{3}$ and \\ Mohamed I. Abdelwahab Hassan 4,5,6 \\ 1 Pharmaceutical and Drug Industries Research Division, National Research Centre, 33-El-Bohouth St. (former \\ El Tahrir St.), Dokki, P.O. Box 12622 Giza, Egypt; dinaelghwas7781@yahoo.com \\ 2 Biology Department, Faculty of Science, University of Jeddah, Jeddah 21577, Saudi Arabia \\ 3 Microbiology Department, Faculty of Science, Ain Shams University, 11566 Cairo, Egypt; \\ elkas_1111@yahoo.com \\ 4 Jena Microbial Resource Collection, Leibniz Institute for Natural Product Research and Infection \\ Biology_Hans Knöll Institute, 07745 Jena, Germany; mohamed.iasmael@gmail.com \\ 5 Department Microbiology and Molecular Biology, Institute of Microbiology, Faculty of Biological Science, \\ Friedrich, Schiller University Jena, 07743 Jena, Germany \\ 6 National Research Centre, 33-El-Bohouth St. (former El Tahrir St.), Dokki, P.O. Box 12622 Giza, Egypt \\ * Correspondence: Khaled.a.selim@gmail.com
}

Received: 7 January 2018; Accepted: 23 February 2018; Published: 8 March 2018

\begin{abstract}
Scarcity of the non-renewable energy sources, global warming, environmental pollution, and raising the cost of petroleum are the motive for the development of renewable, eco-friendly fuels production with low costs. Bioethanol production is one of the promising materials that can subrogate the petroleum oil, and it is considered recently as a clean liquid fuel or a neutral carbon. Diverse microorganisms such as yeasts and bacteria are able to produce bioethanol on a large scale, which can satisfy our daily needs with cheap and applicable methods. Saccharomyces cerevisiae and Pichia stipitis are two of the pioneer yeasts in ethanol production due to their abilities to produce a high amount of ethanol. The recent focus is directed towards lignocellulosic biomass that contains $30-50 \%$ cellulose and $20-40 \%$ hemicellulose, and can be transformed into glucose and fundamentally xylose after enzymatic hydrolysis. For this purpose, a number of various approaches have been used to engineer different pathways for improving the bioethanol production with simultaneous fermentation of pentose and hexoses sugars in the yeasts. These approaches include metabolic and flux analysis, modeling and expression analysis, followed by targeted deletions or the overexpression of key genes. In this review, we highlight and discuss the current status of yeasts genetic engineering for enhancing bioethanol production, and the conditions that influence bioethanol production.
\end{abstract}

Keywords: bioethanol; fermentation; metabolic engineering; biofuel; Saccharomyces cerevisiae; Pichia stipitis

\section{Introduction}

The excessive usage of fossil fuels to satisfy the rapid increase of energy demand has created severe environmental problems, such as air pollution, acid rain, and global warming [1]. All over the world, Humans are constantly based on biomass-derived energy and carbon for survival and nutrition. Also, in late history for the commodity fuels and chemicals we became dependent on petroleum-derived energy and carbon. In the non-renewable petroleum-based carbon, the carbon is sitting in biomass, where the biomass is a temporary store unit for the sunlight and atmospheric carbon derived energy. In the last century, there are rising requests to implement and to improve strategies for production of commodity fuels and chemicals from biomass compared to petroleum. 
To compete with the existing process of petroleum production, the fermentation process should be more efficient, or comparable for maximum production of the targeted chemical. Therefore, the production of petrochemical and biofuels by means of microbial fermentation of agriculture wastes could be our alternative way. Yeasts have advantages over bacteria for commercial fermentation due to the thickness of their cell walls, less stringent nutritional requirements, large sizes, utmost resistance to contamination, and better growth at acidic $\mathrm{pH}$. Saccharomyces cerevisiae and Pichia stipitis are one of the most promising model organisms in microbiological fermentation due to their abilities to produce a high amount of ethanol. They are able to utilize diverse substrates that are full of carbohydrates through fermentation processes. Besides, they are resistant to high ethanol concentrations. The recent focus is directed towards lignocellulosic biomass, which contains 30-50\% cellulose and $20-40 \%$ hemicellulose, and can be transformed into glucose and fundamentally xylose after enzymatic hydrolysis. In nature, the second most abundant carbohydrate is xylose, and it could supply an alternative fuel source for its ability to be commercially fermented into ethanol. S. cerevisiae counts as the main and the most important source of bioethanol production at the industrial level. However, several attempts were implemented to engineer $S$. cerevisiae to transport and ferment xylose because naturally it does not use xylose. Moreover, genetic engineering can upgrade the fermentative activities of some native xylose-metabolizing yeast like $P$. stipitis. In this review, we point out the current status of yeasts genetic engineering approaches for enhancing bioethanol production, and discussing the factors that affect positively/negatively on the fermentation process.

The processes of bioethanol production from the utilization of starch, sugarcane, and microbial fermentation of sugar compounds considers as the main source to dispense with classical fuel which causes noticeable pollution for our planet. Researchers who work in the field of fermentation give more attention for lignocellulose, as it is an alternative and promising way for bioethanol production in our future research [2]. It is known as feedstock that is more plentiful and substantial issue in our environment and does not compete with the sources of food supplies [3]. Although, the central predicament for bioethanol production from lignocellulose conversion is economic status where the production cost should be reasonable. The status that reduces the performance efficiency of yeast is that it has many drawbacks as increasing the concentration of harmful process conditions and toxic chemicals with low tolerance capacity, which is prevented energetically and economically [4].

Bioethanol is the most common source of the biofuel, and about $90 \%$ of total biofuel usage is based on bioethanol production. The process of conventional bioethanol production is well known to be dependent on the enzymatic transformation of starchy biomass into sugars and/or fermentation of 6-carbon sugars with final distillation of ethanol to fuel grade. Ethanol can be produced from various feedstocks such as corn (maize), sugar beets, other cereal crops, sugar cane, cassava, sorghum, and potatoes. Animal feed (co-products) helps in decreasing the production cost as well. Also, bagasse (crushed stalk) is used to supply power and heat for energy applications. Additionally, the biggest bulk of agriculture biomass is composed of lignin, cellulose, and hemicelluloses, which could extend our sustainable and renewable resources for usage in ethanol production $[5,6]$. According to the two largest ethanol producers USA and Brazil, the major sources of ethanol production are maize starch and sucrose from sugar cane [5,7]. The fermentable sugars like mannose, glucose, hexoses, arabinose and xylose can result from hemicelluloses and cellulose fractions of agro-industrial residues either by chemical hydrolyses or enzymatic ones [8]. Currently, researchers in the field of fermentation exert more effort and focus on enhancing the production of ethanol through the bioconversion of lignocellulose for reducing the dependence on the non-renewable energy. Lignocellulose is one of the promising and ample sources, which consists of lignin, cellulose, and hemicellulose [9]. Conversion, the hemicellulose and cellulose to ethanol, occurred through several processes that initiate with different pre-treatment (mechanical, chemical, or both).

An effective transformation of all sugars sitting in lignocellulosic hydrolysates to ethanol is necessary for maximizing the profitability of the industrial process and for reducing the competitiveness cost of bioethanol production [10]. Bio-production of ethanol from lignocellulosic 
material has to be at an acceptable rate, in high yield, and at concentrations that are economically retrievable. The major impediment of cellulose fermentation is the enzymatic saccharification. For hemicellulosic, the utilization of multiple sugars of arabinose, rhamnose, xylose, galactose, mannose, and glucose in the presence of ferulic and acetic acids, along with diverse disintegration products from thermal and chemical pretreatment, is the limiting factor of the fermentation process. Phosphorylation of hexoses compound is occurs once getting in the cell; diverse biochemical stages should be applied for hemicellulosic components before phosphorylation [11].

The pentoses microbial biotransformation has been recognized as the main research challenge for the second-generation ethanol technology because it represents about $25-40 \%$ of the total sugars transformation [6]. The major lignocellulosic biomass component is D-Xylose. For efficient economical lignocelluloses bioconversion, the alcoholic fermentation of this renewable carbon sources (D-Xylose) is required [12]. The pentose sugar xylose from plant hydrolysates cannot be fermented by Saccharomyces cerevisiae (wild types strains), which is the communally used for ethanol production. Therefore, to solve this problem, many attempts to generate genetically recombinant strains of $S$. cerevisiae and P. stipitis, to improve the capability of xylose fermentation into ethanol, have been reported. However, the large-scale industrial process of bioethanol production is limited due to poorly understanding of yeasts metabolic regulations [13]. Additionally, our knowledge for the efficient utilization of lignocelluloses hydrolysates with such yeast strains under the industrial conditions is still limiting [14].

The production of biofuels from lignocellulosic biomass remains an unsolved challenge in the industrial biotechnology. Efforts to use yeast for biofuels production face several questions: of which organism to be use, counterbalancing the ease of genetic manipulation with the promise of robust industrial phenotypes. Saccharomyces cerevisiae remains the premier host for metabolic engineering of biofuel pathways, due to the availability of many systems and synthetic biology tools to for genetic manipulation [15]. When compared to other types of microoganisms, Saccharomyces cerevisiae is the common microbes employed in ethanol production due to its high ethanol productivity, high ethanol tolerance and ability of fermenting wide range of sugars. However, there are still some challenges in yeast fermentation that inhibit ethanol production, such as the high temperature, the high ethanol concentration, and the ability to ferment pentose sugars [16].

Yeasts such as Pachysolen tannophilus, P. stipitis, Candida tropicalis, and Candida shehatae have been detected to ferment one of the most abundant pentoses sugars (xylose) to ethanol. However, the wild-type strains of these yeasts are unable to ferment simultaneously the hexoses and pentoses sugars. Therefore, the creation of genetically modified strains has been notified as special fermentation strategies to introduce new pathways to stimulate the ability for simulations transformation of pentoses and hexose sugars [17]. Co-culture of Zymomonas mobilis bacterium and yeasts was also studied to prove the potential synergistic utilization of different microorganism metabolic pathway [18]. For examples, co-culture of P. stipitis and S. cerevisiae immobilized with Z. mobilis has been studied. Also, co-cultivation of P. tannophilus and Z. mobilis has been investigated using synthetic media with a different combination of xylose and glucose $[10,19,20]$. The wild-type strain of Z. mobilis was isolated originally from alcoholic liquids in natural environments containing fermentable sugars, and can only utilize a limited carbon source, including glucose, fructose, and sucrose [21].

The formation of cell inhibitory substances like phenolic compounds, furan derivatives and weak acids is another important factor implicated in the production of bioethanol (second-generation), the formation of those substances always occurs during the chemical hydrolyses of lignocellulosic materials [22,23]. High level of the toxic byproduct compounds that form during the production of lignocellulosic hydrolysate, is challenging as well. The released acetic acid and furfural during sugarcane hydrolysis can reach up to $5 \mathrm{~g} / \mathrm{L}$ [24], while after the processing of chipped pine wood hydrolysate, hydroxymethylfurfural (HMF) can be reached up $6 \mathrm{~g} / \mathrm{L}$ [25]. The overall cell physiology is affected by such inhibitors and leads to decrease in the strains productivity, ethanol yields and cell viability [26]. For example, furan at high concentrations causes an inhibitory effect on S. cerevisiae, 
interfering with macromolecules syntheses and glycolytic enzymes. Whereas, in the process of lignocellulosic hydrolysis, the acetic acid released, has cytotoxic effects at elevated concentrations [27].

The interest in studying catabolic pathway of xylose utilization has been grown [28-30], with the discovery of pentose-fermenting yeast strains [31,32]. The bio-renewable chemicals and fuels fermentative production need the biocatalysts engineering that can quickly and efficiently transform sugars to the target products with lower cost than the existing petrochemical-based processes. For instance, for eight known reactions required for conversion of xylose to ethanol by Saccharomyces cerevisiae, Latimer and Dueber in (2017) screened several key enzymes for functional expression in S. cerevisiae, followed by a combinatorial expression analysis to achieve a pathway flux balancing and to identify the rate limiting enzymatic steps [33].

Scientists have changed the biocatalysts processes slowly by choosing desirable traits without understanding the biological mechanisms. However, after the evaluation of recombinant DNA technology and the elucidation of the biological code, we became able to do more than choosing the naturally or evolved strains under the selective evolutionary pressures. Nowadays, scientists could design and evaluate proteins, metabolic pathways, and even engineer whole desirable strains. Therefore, the modern thinking is directed in the form of metabolic engineering. Bailey (1991) and Stephanopoulos and Vallino (1991 and 1998) defined the metabolic engineering as the direct advance technology for formation and production of desirable cellular properties through the alteration of biochemical pathways or through using the recombinant DNA technology for the introduction of new traits [34-36].

For the production of a target compound, the synthetic biology can be expressed as a sequence of the following events: (1) designing the phenotypic properties and the metabolic pathways of the wanted system. What are the required products and substrates? What are the predictable environmental stressors? (2) Selecting the suitable host organisms depending on the following criteria. Which organisms display some of the wanted properties? The characters of these organisms and the availability of molecular biology tools for the modulation of this chassis. (3) Formulating an implementation approach. What modulations are needed to obtain the properties and pathway in the first step? Does the targeted metabolic pathway require to be removed, added or tuned? Does the required phenotype or pathway exist in nature or does it need to be prepared de novo? (4) Optimizing of the redesigned system and assessing the properties of the system relative to the ideal processes.

Also, a simple biocatalyst like Escherichia coli, which is the laboratory workhorse, is a complex system of an estimated 2077 reactions, 4603 genes, and 1039 unique metabolites [37,38]. However, the steps outlined above are relatively simple, it is hard to rapidly engineer a biocatalyst to perform the desirable behaviours [39]. The metabolic evolution, the standardization of biological systems and the systems biology are all important to compensate for the disconnecting between actual biocatalyst behaviours and the expected one. Through the combination of all of these powerful techniques, the biocatalysts redesigned for the production of chemicals and commodity fuels can be achieved (Figure 1).

For heterologous gene expression, yeasts become important hosts [40]. It is necessary to control gene expression quantitatively for optimal metabolic engineering. Williams and Bowles (2004) found the co-expression of neighboring genes in Arabidopsis [41]. This type of expression has been observed in many eukaryotic genomes [42-44]. The same orientation of the genes has been proposed as one of the mechanistic explanation for co-expression [41,45]. For instance, the effects of tandem orientation or divergent gene orientation can exist in co-expressed genes in plants [46,47]. Prescott and Proudfoot (2002) recognized the transcriptional repression of convergently arranged genes in yeast, which was explained by the transcriptional collision [48]. These findings suggested that intergenic regions among adjacent genes, which have significant roles in transcription. Scratching of regions between the two ORFs caused reduction of yeast transcript $[49,50]$. The intergenic region in S. cerevisiae was found to have a regulatory function [51,52], and according to the orientation of neighboring ORFs, they have different base compositions [53]. 


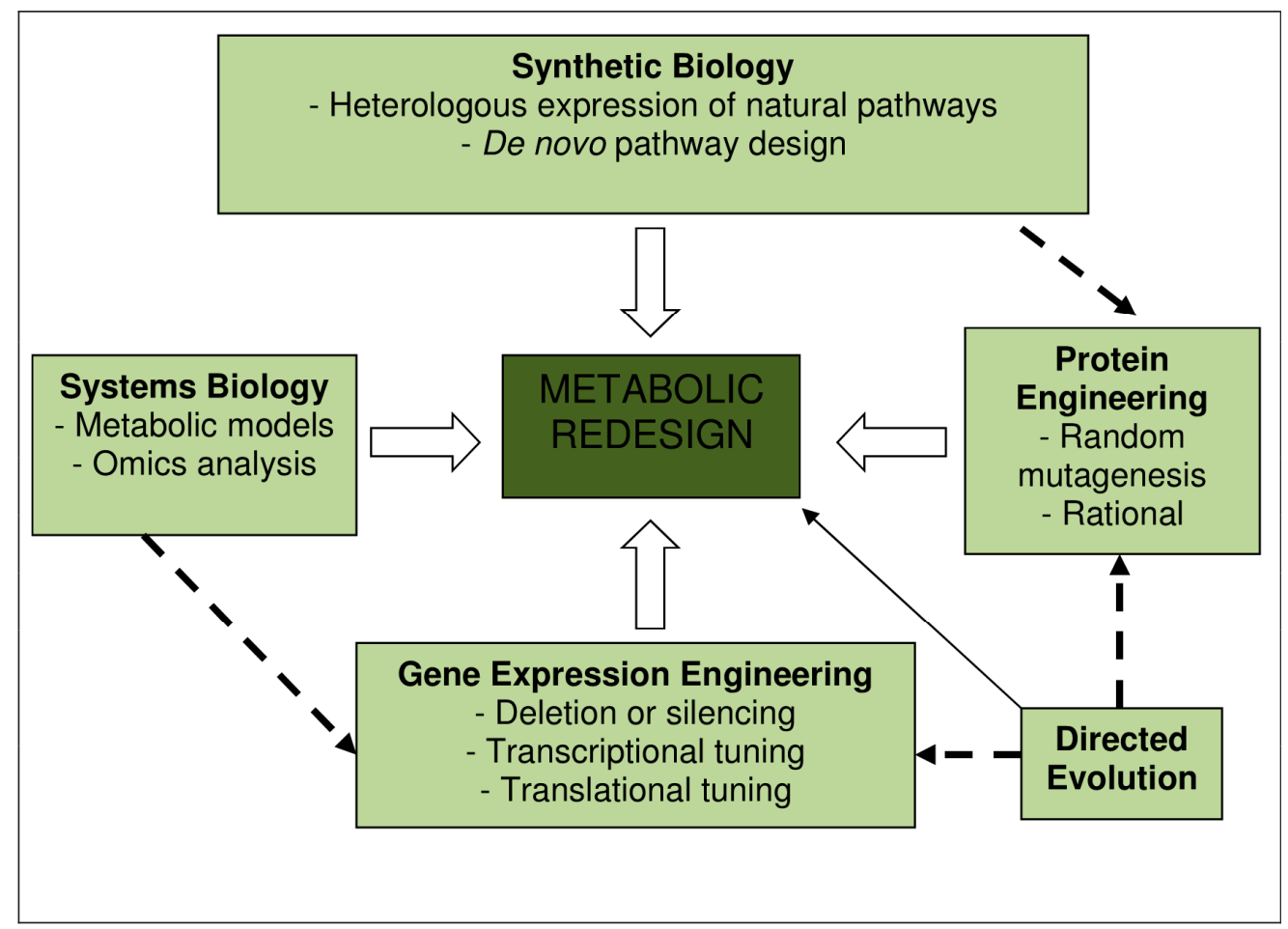

Figure 1. Overview of tools for the metabolic redesign.

Technical, economic, and political considerations are the driving force for improving the fermentation of xylose to ethanol. For instance, the renewable fuel production using biological biomass as a feedstock can lead to a decrease in the accumulation of greenhouse gasses [54-57]. Therefore, the European Union recommended that biofuels should appear $2 \%$ by 2005 of total transportation fuel consumption and $5.75 \%$ by 2010 [58]. Moreover, the agricultural policies of the European Union, Brazil, and United States are directed towards the ethanol industries for the commercial production of ethanol from sugar cane, grains, and other feedstock. The chance for the processing residues and the bioconversion of harvested agriculture materials are increasing along with these markets. For instance, the usage of sugarcane bagasse, corn cobs, grain hull, and corn cobs byproducts to increase the production of ethanol from the waste streams becomes feasible $[59,60]$. While the major component of the renewable biomass feedstock is the xylose, thus, the technical barrier for commercial bioconversion of feedstock is the active utilization of xylose [61,62]. Half of the word agriculture phytomass containing lignocellulosic crop residues [63], and without competing with other lignocellulosic-based industries, considerable fractions can be recovered [56,64]. In woody angiosperms, xylose constitutes is about $17 \%$ of the total dry weight, and in herbaceous angiosperms, it can be up to $31 \%[65,66]$. The sulfite-pulping of hardwood is the source of xylose [67]. The pretreatment of lignocellulosic residues can recover $80-95 \%$ of the xylose, depending on the reaction conditions and the substrate $[24,68,69]$.

Native S. cerevisiae strains do not use xylose as carbon sources. Also, the yeast Candida utilis is strictly aerobic and can grow on xylose, but it is not an ethanol producing strain. Early in 1980, after identification the ability of Schizosaccharomyces pombe, S. cerevisiae and other yeast strains to ferment D-Xylose to ethanol [70,71], a lot of screening effort rapidly detected that some strains could convert xylose to ethanol immediately under oxygen-limiting or aerobic conditions [32,72]. Nowadays, Pichia stipitis, C. shehatae, and Pachysolen tannophilus attract a lot of attention as the best known natural xylose-fermenting yeasts [73-75]. Although the technical and economical biotransformation of pentoses sugars to ethanol are still challenging [12,76-79], many achievements in genetic engineering have been done to ferment arabinose and xylose to lactic acid and ethanol. 
The development of yeast strain mainly focuses on the genetic engineering of S. cerevisiae. However, for xylose fermentation, $P$. stipitis has also been modified. Metabolic engineering can change the pentose phosphate pathway, sugar transport, assimilation, the terminal steps of fermentation, glycolysis and the interlayer between fermentation and respiration that influence the intracellular redox balance. Whereas, few alternations could make xylose utilization in S. cerevisiae possible, where; in $S$. cerevisiae, the genes for xylose assimilation exist, but they are not expressed at a considerable level that can be sufficient for xylose fermentation. Engineering of $P$. stipitis has been more restricted; however, some principles have been identified in this yeast.

$P$. stipitis has a set of physiological characters that make it very helpful for lignocelluloses bioconversion. It has a high capacity for xylose fermentation. Also, it is able to ferment cellobiose, glucose, mannose, and galactose along with xylan oligomers and mannan. Therefore, it is considered as a potent organism for simultaneous or hydrolysate fermentation and saccharification (SSF). After glucose, the second most abundant hemicellulosic component is xylose in fast-growing hardwood species and agriculture residues. On the other hand, the primary sugar formed in enzymatic hydrolysis is cellobiose [78].

Hemicellulose sugars are easily recovered after the treatment of agriculture wastes with dilute acid, alkali or autohydrolysis, which is crucial for the economical bioconversion. The ability of P. stipitis to use cellobiose is significant in SSF because the commercial preparations of cellulase are always incomplete in $\beta$-glucosidase treatments and the aggregation of cellobiose inhibits cellulase activities. The ability of $P$. stipitis to use oligomeric sugars is necessary because the mild acid pretreatments can bypass the formation of sugar degradation products, but can also resolution $15-50 \%$ of the solubilized hemicelluloses in an oligomeric form [78].

Hemicellulosic sugars are underutilized, however; they can be readily recovered at a lower cost than glucose from cellulose with higher yields. Moreover, they can be transformed into a number of useful products like lactic acid, xylitol and other chemicals. Ethanol is the product that has the largest potential market. Ethanol production from lignocellulosic sources will keep increasing as a consequence of recent agriculture and energy policies to reduce carbon dioxide emissions and alternative renewable fuels [78].

Researchers in many laboratories have scrounged genes from $P$. stipitis and other fermentative microorganisms to alter $S$. cerevisiae for cellulose, xylose, or xylan metabolism. However, to some extent of success, efficient xylose utilization has been achieved by engineered $S$. cerevisiae strains mostly at a low rate of xylose assimilation. The most of biochemical steps required for xylose utilization are understandable; however, a more thorough knowledge of how local xylose-fermenting yeasts, like P. stipitis, adjust their metabolism would improve the field on many fronts [78]. In general, the assimilation pathways for hexoses and pentoses, mannose, glucose and galactose are summarized in Figure 2.

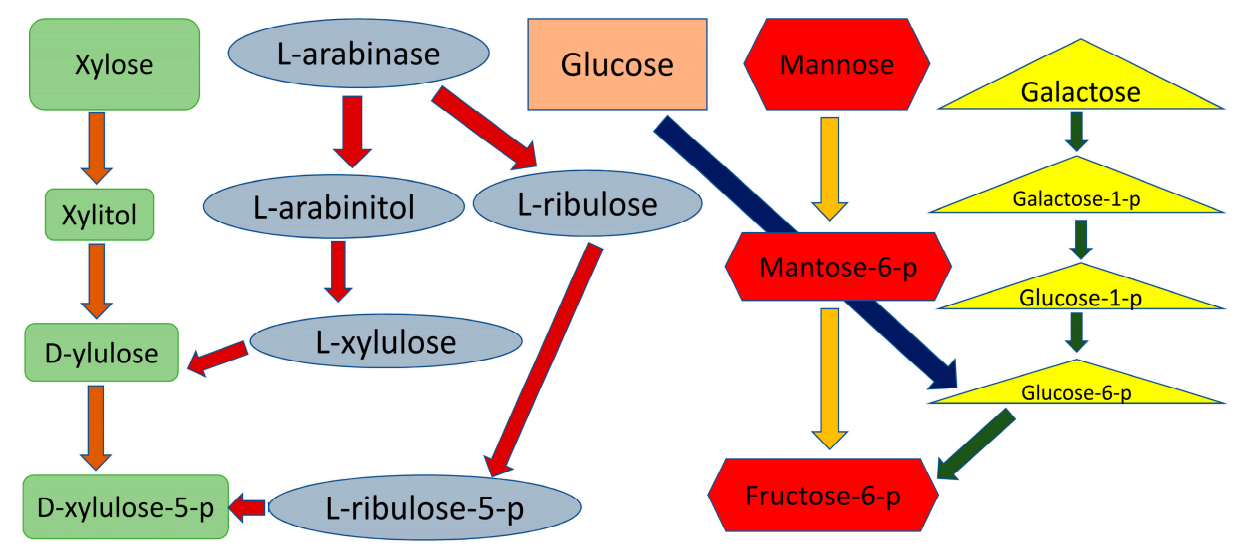

Figure 2. Assimilation pathways for hexoses and pentoses, mannose, glucose and galactose, showing the interconversion of pentoses and pentitols by NAD (PH)-mediated oxidoreductases [11,80]. 


\section{New Yeast for Lignocelluloses Bioconversion}

Intellectual metabolic engineering requires a detailed understanding of the genetic, physiology and biochemistry of the desired strain to be engineered. It is potentially possible only when the main mechanisms and pathways are known. Genetic and biochemical characterization of xylose fermentation by $P$. stipitis has been underway for at least 22 years since the evaluation of mating systems [79] and developing genetic transformation tools [81-83]. Moreover, the researchers are still aiming to improve and enhance the xylose utilization by P. stipitis, despite the fact that the capability of the native strains to produce high amounts of ethanol than any other studied yeast, including the genetically engineered $S$. cerevisiae $[84,85]$.

The native P. stipitis strains were originally isolated from insect larvae. Phylogenetically, it is related to the endosymbionts gut microbiota, which inhabits the passalid beetles gut [86] that degrades white rotted hardwood [87]. Genetically and systematically, P. stipitis is predominantly homothallic, haploid and hemiascomycetous yeast $[79,88-90]$ that forms buds along with pseudomycelia during vegetative growth, and two hat-shaped ascospores from each ascus. Fed-batch cultures of $P$. stipitis produce up to $47 \mathrm{~g} / \mathrm{L}$ of ethanol from xylose at $30^{\circ} \mathrm{C}$ [85] with ethanol yields of $0.35-0.44 \mathrm{~g} / \mathrm{L}$ xylose [91]. Moreover, they are able to ferment sugars from hemicellulosic acid hydrolysates with a yield equal to about $80 \%$ of the maximum theoretical conversion efficiency [92,93].

The genomes of $P$. stipitis strains are encoding for xylanase, mannases, cellulases, and other degradative enzymes that enable them to grow and survive in the insect-gut environment of wood-inhabiting [86]. P. stipitis has the ability to ferment xylan, xylose [94,95], and cellobiose and to use all the main sugars that found in wood containing rhamnose and arabinose [96]. Therefore, P. stipitis genome was considered to be the popular genes source for xylose metabolism to engineer S. cerevisiae [80].

Additionally, P. stipitis has many other bioconversion related traits: forming various esters and aroma components [97], reducing acyclic enones to the corresponding alcohols [98], modifying low-molecular-weight lignin moieties [99], and can be engineered to produce xylitol [100] or lactic acid [101] in high yields. Also, P. stipitis strains are resistant to hydroxyl-methyl furfural and furfural [102].

Adaptive evolution and metabolic engineering of $S$. cerevisiae for fermentation of xylose were successful to certain degrees [103-105]. Engineering S. cerevisiae with the basic xylose assimilatory machinery with expressing xylose reductases, xylose isomerase [13,106] and xylitol dehydrogenases [107] can theoretically enhance the ethanol yield. However, it is unclear until now which approach would demonstrate more success to improve the fermentation capability of S. cerevisiae [108].

Likewise, the overexpression of $P$. stipitis and other fungal sugar transporters can enhance the performance of engineered S. cerevisiae to grow and uptake xylose [109-112]. However, additional regulatory steps are required to engineer an efficient ethanol producer $S$. cerevisiae strain, because the mechanism for production of ethanol in response to xylose in S. cerevisiae is missing [113]. Thus, nowadays the biochemical, physiological, and genetic regulations of P. stipitis and other yeasts that use the unusual substrates natively, have attracted a lot of attention, for engineering S. cerevisiae strains which have capability to ferment rhamnose, cellulose, xylose, arabinose, xylan [96], and other sugars residue. Conversely, the $S$. cerevisiae mechanisms for xylose fermentation can be used for developing the performance of $P$. stipitis.

P. stipitis maneuvers most of its metabolic flux into ethanol production and very small amount of xylitol can be formed as well. However, its fermentation rate on xylose is low when compared to that of S. cerevisiae on glucose. Xylose and glucose are not equal fermentations for many reasons, but increasing the capacity of $P$. stipitis for rapid xylose fermentation can greatly develop its usefulness in commercial applications. One of fermentative regulatory machinery is that $S$. cerevisiae regulates fermentation process by sensing the existence of glucose, but $P$. stipitis promotes fermentative activity in response to oxygen limitation [114-117]. Universal expression array analysis has shown special response patterns for rahamnose, cellobiose, arabinose, xylose and other lignocellulosic substrates. But, it is not fully understood until now whether these patterns were related to specific induction or carbon 
catabolite depression. Additionally, termites are known as xylophages, because they are able to feed on the various sources of lignocellulosic biomass as wood, which are characterized by massive amount of lignin. This capability comes from the symbiotic relationships between the termites and their gut microbiomes. Termite-gut microbiomes can be utilized for enhancing biomass conversion processes in vitro [118]. Interestingly, Physisporinus vitreus depends on unprecedented versatile peroxidase (VP) strategy that helped to characterize novel delignification delineation. This strategy played vital role in enhancing oxidization both phenolic and nonphenolic units of lignin and breaking various linkages in lignin. This recent discovery shed the light on the value of VP in enormous applications of biotechnological processes [119].

\section{Pentose Phosphate Pathway}

The biochemical route for xylose metabolism is the pentose phosphate pathway (PPP), which sets in all cellular organisms where it supplies D-erythrose 4-phosphate for aromatic amino acids synthesis, D-ribose for biosynthesis of nucleic acid, and NADPH for the anabolic reactions. The PPP is composed of two functionally interrelated branches: the oxidative and the non-oxidative [120]. The oxidative phase that transforms the D-glucose, hexose into D-ribulose 5-phosphate, NADPH, plus $\mathrm{CO}_{2}$ and pentose. The non-oxidative phase that transforms D-ribulose 5-phosphate into D-glyceral-dehyde 3-phosphate, D-xylulose 5-phosphate, D-ribose 5-phosphate, D-fructose 6-phosphate, D-sedohep-tulose 7-phosphate, D-erythrose 4-phosphate, L-arabinose, and D-Xylose come in the PPP over D-xylulose (Figure 3). The transformation of D-xylose to D-xylulose in bacteria goes by way of xylose isomerase $(x y l A)$. In yeast, some eukaryotes and filamentous fungi, this process has done by a two-step oxidation and reduction that is mediated by xylitol dehydrogenases (Xyl2p, XYL2) and xylose reductase (Xyl1p, $X Y L 1)$, respectively. The requirement of cofactor of these two reactions is influenced by the cellular demands for oxygen [121].

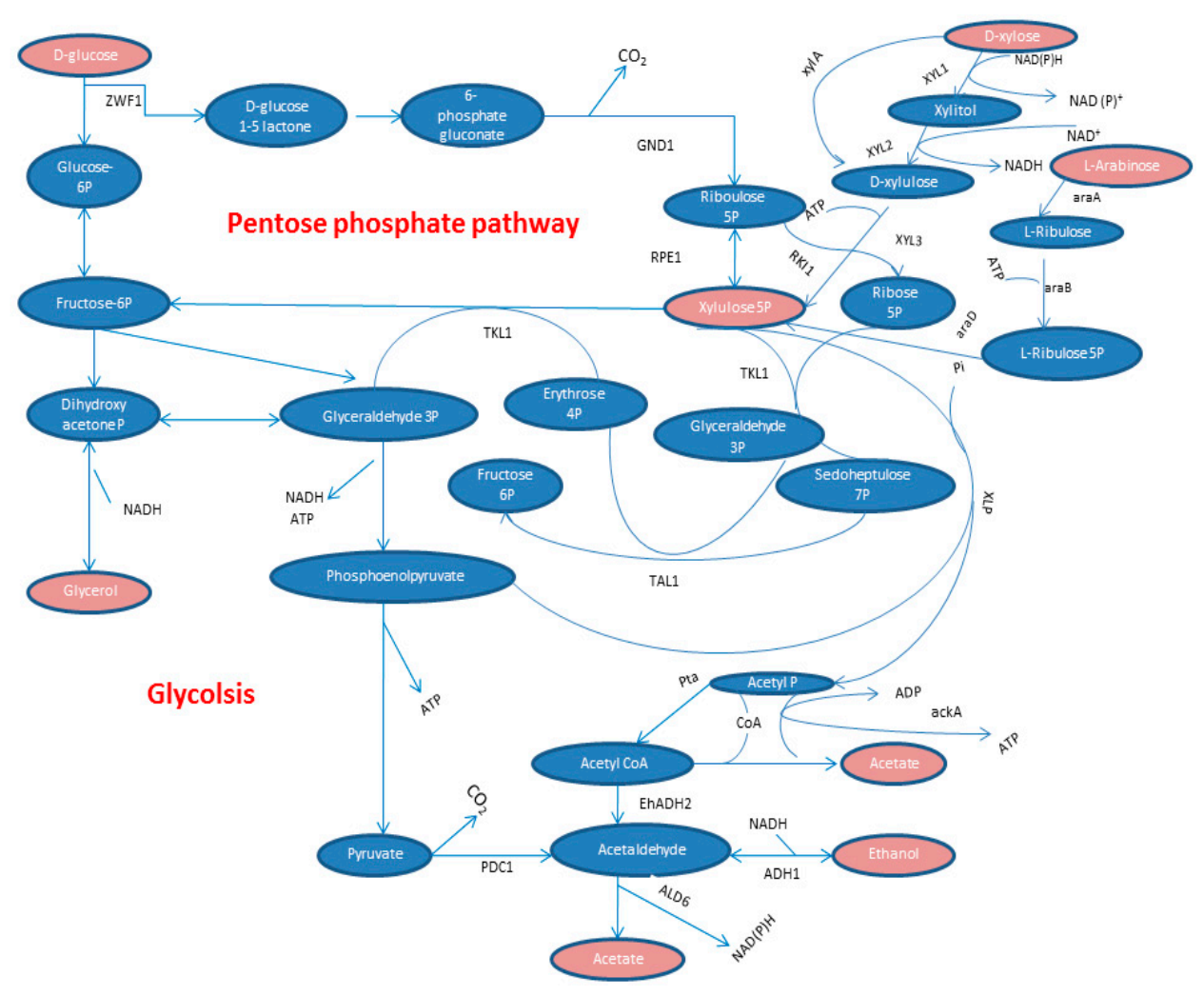

Figure 3. The pentose phosphate pathway (PPP) in yeasts. 
Kötter and Ciracy (1993) proposed that, the excessive xylitol production by genetically engineered S. cerevisiae with xylose reductases (XYL2 and XYL1) was restricted by the dual cofactor ability of the $P$. stipitis xylose reductases, the excessive activity of the oxidative PPP in $S$. cerevisiae, and by the incomplete ability of the non-oxidative PPP [122]. Overexpressing of transketolase (TKL1) from $P$. stipitis in an engineered S. cerevisiae causes a reduction in the growth rate of the new transformant mutant on defined xylose minimal medium [123]. The overexpressing stains of $P$. stipitis transaldolase (TAL1) gene, along with XYL2 and XYL1 implant faster growth than strains expressing XYL2 and XYL1 alone [124]. However, the plasmid burden because of the overexpression of XYL1, XYL2 and TAL1 decreased the rate of growth of the trans formant strain relative to the parental strain $[125,126]$. Sinorhizobium meliloti (gram-negative bacteria) defined as a model organism for investigating the plant-microbe interactions, because it participates in process of nitrogen fixation as it has symbiotic relationship with Medicago sativa and M. truncatula. Mutation in the gene $t k t 2$, a putative transketolase and tal, a putative transaldolase had remarkable influence on the non-oxidative branch of the pentose phosphate pathway, acquisition of iron and several physiological processes such as the biosynthesis of exopolysaccharide [127].

\section{Xylose Isomerase Mechanism}

The engineering of Saccharomyces cerevisiae for xylose utilization is an essential step towards the production of this biofuel. Though xylose isomerase (XI) is the key enzyme for xylose conversion, almost half of the XI genes are not functional when it is expressed in S. cerevisiae. However, XI from Piromyces sp. E2 (PirXI) can be used to equip Saccharomyces cerevisiae with the capacity to ferment xylose to ethanol $[128,129]$. For xylose assimilation, the initial metabolic engineering endeavor was achieved by the heterologous expression of xylose isomerase (XI) in S. cerevisiae. This process was feasible, given that $S$. cerevisiae was able to grow and ferment xylulose. However, the considerable activity of xylose isomerase was not fulfilled in the overexpressing strain, probably due to protein misfolding [76,77]. Moreover, if a little amount of the XI protein was properly folded and was active, the competitive inhibitor xylitol would be formed [130]. Later, the heterologous overexpression of XI from thermophilic bacterium Thermus thermophiles in the background of genetically modified S. cerevisiae, attained successfully the production of an active XI enzyme to decrease xylitol production [131,132]. However, the optimum temperature for the best activity of T. thermophilus XI is higher than the required temperature for the optimum growth of Saccharomyces. Recently using direct evolution approach, the activity of XI could be enhanced more nine-fold than previous studies at a higher temperature of $60{ }^{\circ} \mathrm{C}$ and for xylitol much higher inhibition constants [133]. Recently, eukaryotic XI has been identified, followed by the introduction of XI from anaerobic fungus (AraA) into S. cerevisiae [103]. The transformation of $S$. cerevisiae with AraA enhanced slowly the utilization rate of xylose assimilation [134]. Additionally, the fruitful use of XI depends on other factors. At equilibrium, the energetic rate of the isomerization between xylulose and xylose support xylose formation by 17:83 [135], therefore, another driving force is necessary to promote the reaction. Additionally, a recent study pointed out the importance and relatedness of engineering of metal homeostasis to metabolic pathways for balancing metal-dependent enzymes. It focused on the role of metal interactions of heterologous XIs in engineering xylose metabolism in S. cerevisiae [136].

\section{Pathway of Xylose Reductase and Xylitol Dehydrogenase}

The existence of an aldose (xylose) reductase $(X R)$ is considered as the main factor for assimilation of xylose by native anaerobic yeasts like Pachystolon tannophilus that might utilize and use either NADPH or NADH as a cofactor [80]. These results were confirmed by an earlier study that used Candida utilis for the utilization and assimilation of xylose. The utilization and assimilation of glucose by this yeast was easy during the fermentation process; however, the fermentation activity refrains directly once the use of xylose as a substrate. Solely, the C. utilis XR utilizes NADH as a cofactor. While, the XR of Pichia stipites, Pachysolen tannophilus and Candida shehatae can utilize either NADPH or 
NADH as cofactors through the fermentation process [80]. They assimilate and have the capability to utilize xylose anaerobically, although they do not grow natively under such conditions [137]. Two oxidoreductase steps are essential for completing the assimilation processes of xylose, and they are the main core for balancing the oxidoreductase reactions, so the regeneration of $\mathrm{NAD}^{+}$ and NADPH in the absence of transhydrogenase ceased the xylose assimilation under anaerobic conditions. This evidence was confirmed by cloning and heterologous overexpressing the P. stipites XR in S. cerevisiae [80], where the overexpressing mutant strain produced xylitol when differential sources of carbon were represented to provide reductant [137]. The assimilation, utilization of xylose, and the production of xylitol were inhibited, when glucose was used in the media as co-substrate, probably due to competition for transport $[138,139]$. However, P. stipitis XYL1 does not have such an impact on xylose assimilation [140]. For maximum ethanol production, it requires a system where the reduction of acetaldehyde under limited oxygen conditions is possible, and additionally oxidation of xylitol to xylulose [80]. The capability of $S$. cerevisiae to assimilate and utilize xylose was clearly observed with the isolation and transformation of two XR genes (XYL1 and XYL2) from P. stipites, which were responsible for the assimilation of xylose $[141,142]$. The genetically engineered $S$. cerevisiae with those two genes had the ability to utilize xylose by oxidation processes and generate xylitol in the absence of any additional co-metabolizable carbon sources for xylose assimilation processes. Furthermore, in a combination of XR with xylitol dehydrogenase $(X D H)$, the ethanol production was enhanced while the xylitol production was decreased because augmentation the activity of xylitol dehydrogenase $(\mathrm{XDH})$ is proportional to $\mathrm{XR}$ activity $(\mathrm{XDH}: \mathrm{XR}=1.66)$ as compared to $\mathrm{XR}$, which was expressed in abundance [143]. Whereas, the overexpression of XYL2 causes the secretion xylulose, reflecting that the activity of xylulokinase (XK) inhibits the assimilation and utilization of xylose on such cells [144]. Candida glycerinogenes, expressing the xylitol dehydrogenase (XYL2) gene, and can produce glycerol from xylose that has observable role in pentose phosphate pathway. Minimal expression levels of the XYL2 gene originated from Scheffersomyces stipitis in C. glycerinogenes has a distinguished role in enhancing the efficiency of xylose fermentation [145]. An engineered strain that has both wild XR and mutant XR showed lower xylitol accumulation and faster xylose consumption than engineered strains overexpressing only one type of XRs. This result emphasized the role of XR genes in enhancing the quantity of produced ethanol [146].

\section{Xylose Transport}

S. cerevisiae did not properly utilize the xylose due to the low affinity of its natural nonspecific hexose-transport system for xylose. The heterologous overexpression of a specific xylose transporter has an apparent influence on biotechnological ethanol production, so a lot of researchers focused on that issue. Candida intermedia have several indications that strengthen the probability the presence of xylose transporters, such as constitutive facilitated diffusion of xylose, glucose-repressible and high xylose affinity. Two transporters from this yeast already are described. They are known as GXF1 (glucose/xylose facilitator) and GXS1 (glucose/xylose symporter) transporters. Facilitated diffusion does not require high energy for sugar uptake as compared to proton symport, so the facilitator protein considers as promising method especially in the scarcity of ATP production and absence of oxygen sources [147]. Furthermore, a gene encoding xylose/glucose proton transporter isolated from Candida intermedia was introduced to $S$. cerevisiae, which in turn, improved the xylose utilization with $K_{m}$ of $200 \mu \mathrm{M}$ for xylose, but the $K_{m}$ was 10 folds lower for glucose [110,147]. GXF1 and GXS1 are transporters that play an important role in enhancing the utilization of glucose 10-fold higher than xylose. The expression of Gxs1and $G x f 1$ is directly proportional to the concentration of glucose [112]. At the high concentrations of xylose, $G \times f 1$ had no distinguishable influence on a xylose engineered S. cerevisiae strain, but it boosted growth remarkably at low concentrations [148]. Trxlt1 transporter, which was identified in Trichoderma reesei, increased the growth opportunity on xylose, but not on glucose, which reveals that it may be particularly a xylose transporter [110]. 
It was proposed that the native xylose-fermenting yeast Pichia stipites has specifically high-affinity xylose uptake systems, and low uptake systems shared for xylose and glucose transport [77]. Sut1-3 transporters are the most prominent glucose transporters in P. stipites; they can transport the monosaccharides compounds, such as xylose and glucose. Notably, the induction of Sut 1 gene in S. cerevisiae increased the xylose transport activity for efficient ethanol bioconversion during the fermentation process [149]. Sut2 and Sut3 are highly analogous to the glucose transporter systems in S. cerevisiae, but they have a lower affinity for xylose than for glucose. The induction of the transcript of Sut 1 gene in P. stipitis has not correlated with the oxygen concentration; however, Sut2 and Sut 3 genes are highly expressed definitely under aerobic conditions only, but the variation in the available carbon supply does not affect the transcript [80]. Mutational analysis of Sut1 gene excluded the transport system of low-affinity xylose in P. stipitis. In $\Delta$ sut1 mutant grown under oxygen-deficient conditions where the other identified Sut2-3 systems were inactive, showed clear xylose transport activity. Such results indicated the presence of other unidentified specific xylose transporters, besides the low affinities Sut1-3 transporters [80]. However, the initial work of Weierstall et al. (1999) was unable to identify cross-hybridization signals for Sut or Hxt related transporter genes in the native xylose uptake P. stipites [109].

Utilization of xylose by S. cerevisiae and P. stipitis is restricted by the uptake activity of xylose sugar. The HXT-transporter represents another transport family that is responsible for sugar-transport and uptake of glucose in S. cerevisiae [150]. $\mathrm{H} x \mathrm{t}-\mathrm{H} x \mathrm{t} 7$ with Gal2 transporters showed reciprocal uptake activity especially when overexpressed in $h x t 1-7$ null mutant of $S$. cerevisiae, which sheds light on their function in the facilitated diffusion [151]. There is an irreversible relation between glucose and xylose uptake that clearly confirms that both substrates (xylose and glucose) use the same transporter [152]. Uptake of xylose in S. cerevisiae is occurred by high- and low-affinity systems of glucose transporter [153], however co-incubation with xylose the expression of the high-affinity system can be detected. The limiting conditions of oxygen lead to robustly enhance (5- to 50-fold) the high-affinity transporters $H x t 2, H x t 6$ and $H x t 7$ and they mitigate the affinity of $H x t 5$ transporter when xylose is supplemented in media for xylose-fermenting S. cerevisiae FPL-YSX3 [154]. When YSX3 cells cultivated in xylose, the low-affinity $H x t 1$ and $H x t 3$ transports are expressed at $2-5 \%$ of the level identified for the cells grown on media containing glucose [155]. These results proposed that engineered S. cerevisiae originally utilizes the high-affinity system for xylose transport. The native glucose transporters of $S$. cerevisiae manifest noteworthy low affinity for xylose. Therefore, xylose and glucose are expended altogether only under the limitation of glucose condition [152]. Reintroducing several HXT genes, like $H x t 4, H x t 5, H x t 7$, and Gal2, reinforce the uptake of xylose [156].

Not only the yeast and bacterial species contribute to xylose transport, but also the filamentous fungi participate in bioethanol production. The genome screening of Aspergillus nidulans and Trichoderma reesei revealed the presence of xylose transporters; however, the use of such protein-transporters in fermentation processes cannot be achieved without minor adjustments to enhance their capacity for pentose uptake. Introduction of xylose transport $x \operatorname{tr} D$ from A. nidulans into $S$. cerevisiae could successfully improve the process of sugar transport, and the $x \operatorname{tr} D$-expressing S. cerevisiae mutant was able to grow xylose, galactose, glucose, and mannose with high affinity toward xylose uptake [157].

Furthermore, the original transporters in S. cerevisiae are not precisely controlled for ease uptake of xylose [158]. Novel paradigm of metabolic processes integrated the kinetic characterization of diverse proteins foretells with prompting of sugar transporters. The low concentration of glucose enhances the transport activity of xylose by $S$. cerevisiae since the existence of glucose suppresses the altitude resemblance of hexose transporters that play a vital role in the assimilation of xylose [159]. Xylose transport has a slight influence on the average exploitation of the xylose when the standard xylose reductase (XR) is scarce. Increasing the transporter of xylose has a vigorous potent impact on S. cerevisiae cells, which genetic manipulated for assimilation by overexpression of xylose isomerase (XI) [160]. 
S. cerevisiae lacks specific pentose transporters, which causes disturbance the entrance of pentose in presence of glucose via endogenous hexose transporters (HXTs). The mutant strains of Cyc8 increased expression level of HXTs, by facilitating the transport of xylose. Enhancing the expression of multiple hexose transporters makes D-xylose metabolism less sensitive to D-glucose inhibition, because it increased the transport rate of D-xylose into the cell [161].

\section{Xylulokinase}

Engineering of $S$. cerevisiae to express xylulokinase $(X K)$ was one of the fundamental approaches for improving the bioethanol production. As early as 1988, D-xylulokinase sequences from S. cerevisiae and Pachysolen tannophilus have been described [162-164]. In the yeast genome project, the complete S. cerevisiae gene XK was identified [165]. However, the XK enzyme, which was described by Ho and Tsao in 1993, was found to be inactive $[164,166]$. In S. cerevisiae cells, it is known that the activity of XK limits the xylulose metabolism $[162,163]$. The overexpression of XK from S. cerevisiae (ScXK) along with XYL2 and XYL1 of P. stipitis in Saccharomyces sp. helped the strain to ferment a mixture of $56 \mathrm{~g}$ xylose/L and $53 \mathrm{~g}$ glucose/L to produce about $50 \mathrm{~g} / \mathrm{L}$ of ethanol within $36 \mathrm{~h}$ [167]. This result demonstrated the importance of XK activity and reflected one of the highest ethanol yield obtained by genetically engineered S. cerevisiae with reasonable fast rate of xylose/glucose fermentation [80]. Under aerobic conditions, the overexpression of $S$. cerevisiae XK improves clearly xylose consumption; however, by decreasing the aeration, the xylose utilization drops down [80].

It was reported that in $\triangle X K$ strain, high arabitol levels which in turn enhances the bioethanol production; however, such deletion of XK caused blocking of xylitol formation, which derived from xylose [166]. Additionally, a mutation within the promoter region of phosphoglucose isomerase causes the reduction of the enzyme activity and accumulation of fructose-6-phosphate, which also causes increase in the ethanol yield by 15\% [80]. In native S. cerevisiae, D-xylulokinase is not expressed meaningfully; however, it is crucial for xylulose metabolism as the $\triangle X K$ mutants have a defect to grow on xylulose [163]. Simultaneously, the XK overexpression can cause a defect on the growth of the yeast strain on xylulose [165]. Over unlimited access to xylulose, the severe toxicity accomplished with XK overexpression can be due to depletion in ATP [168-170]. Additionally, Toivari et al. (2001) showed that the intracellular levels of ATP and the ATP / ADP ratio are significantly reduced in such recombinant strains. Nevertheless, the $X K, X Y L 1$, and $X Y L 2$ overexpression diminished the xylose utilization, but improved the ethanol yield [144,169].

Later, $\mathrm{XK}$ from P. stipites (Ps XK) has been overexpressed in an engineered S. cerevisiae background for high expression levels of XYL1 and XYL2 [171,172]. The specificity of P. stipites XK enzyme for D-xylulose was much higher, with less D-ribulose activity than the $X K$ from S. cerevisiae [168]. There was no influence on the growth on xylose, when the activity of $P_{S} X K$ was low. However, the overexpression of PsXK, strongly inhibited the aerobic growth on xylose. Therefore, the toxicity effect of overexpression of $S c X K$ and $P s X K$ increased with aeration. Furthermore, no toxicity effect of XK was observed on glucose-grown cells, and the observed XK activity was much higher, reflecting that the toxicity arose from xylose uptake. With the use of $P_{s} X K$ native promotor, the growth rates and the bioethanol production were optimum. Altogether, the toxicity effect of $X K$ overexpression arose with the full accessibility to D-xylulose, similar to substrate accelerated cell death.

\section{Xylanase and Cellulose}

Most xylanases produce xylotriose and xylobiose as the main oligosaccharides, while the exocellobiohydrolases produce cellobiose, which is important for simultaneous fermentation and saccharification. The wild-type xylose-fermenting yeast $P$. stipitis has genes encoding for endoxylanase and seven $\beta$-glucosidases homologs, which facilitate the utilization of oligosaccharide. $P$. stipitis xylanases allow the direct fermentation of xylan into ethanol, but with very low yields $[94,95]$. The overexpression of xylanase was achieved through a heterologous endoxylanase expression [95,173-175], or through mutation [176], or by amino acid supplementation [177], 
which could improve the fermentation rate of xylan. Notably, S. cerevisiae genome does not encode for natural xylanase; however, several scientists have succeeded to engineer $S$. cerevisiae strains to express heterologously xylanases $[175,178,179]$. For the fermentation of xylotriose and xylobiose, $\beta$-xylosidase enzymes are required because of their abundance as a byproduct of xylanase activity, besides, they are also produced during the acidic hydrolysis of xylan.

A recent study could optimize the concurrent production of cellulase and xylanase in Trichoderma reesei NCIM 1186 in presence of Prosopis juliflora pods. The maximum xylanase activity, 444.94 U/L, was achieved with the highest cellulase activity of $2804.40 \mathrm{U} / \mathrm{L}$. Whereas, the maximum cellulase activity obtained was 3055.65 U/L where xylanase highest activity was $422.16 \mathrm{U} / \mathrm{L}$. They found a tradeoff between the two objectives and the optimal activity value [180].

\section{Xylitol Production}

The production of xylitol from natural xylose-fermenting yeasts like C. shehatae, C. guillermondii, C. boidinii, Hansenula polymorpha and Pachysolen tannophilus depends on species and several cultivations factor mainly, $\mathrm{pH}$ and the aeration conditions, which will be discussed later [181-186]. Notably, the production of xylitol by $P$. stipites is relatively very low, which accompanies high ethanol yields; however, the xylitol productions increase dramatically when alcohol dehydrogenase (ADH) gene is deleted [177,187]. This suggests that $P$. stipitis XDH competes with ADH for reductant, apparently NADH. In native xylose-fermenting yeast $P$. stipitis, the primary ADH is heavily expressed with decreasing the availability of $\mathrm{O}_{2}[116,188]$. Moreover, $P$. stipitis produces xylitol and arabitol, when the xylulokinase is deleted [172].

Recombinant engineered $S$. cerevisiae strains that utilize xylose have a tendency to produce xylitol [166]. It was reported that XYL1 overexpressing S. cerevisiae mutant, produced xylitol in sequential or continuous batches [189]. Later, Jan and his collages (2003) reported that proportional increasing XYL2 expression to XYL1, potentially decreased xylitol levels [172]. They thought that the xylitol production by engineered $S$. cerevisiae strains resulted from an excess of NADPH relatively to NADH for the early assimilation step of xylose [80]. Therefore, the reduction of xylitol production is crucial to raise the ethanol production yield. In (2002), the researchers expressed XKS1 in S. cerevisiae zwf1 and gnd1 backgrounds. The yield of the ethanol production increased in $\Delta g n d 1$ background to be $0.38 \mathrm{~g}$ ethanol $/ \mathrm{g}$ of consumed xylose. Remarkably, in $\Delta z w f 1$ background, the ethanol production was also enhanced, and the mutant was able to produce $0.41 \mathrm{~g}$ ethanol $/ \mathrm{g}$ of xylose, while the parental strain produced $0.31 \mathrm{~g}$ ethanol $/ \mathrm{g}$ [190]. Nevertheless, both of the strains exhibited slow uptake rates of xylose, which specify that the production of NADPH is essential for the assimilation of xylose in S. cerevisiae.

Presumably, the reduction of NADPH concentration with $\mathrm{NAD}^{+}$regeneration from $\mathrm{NADH}$ could diminish xylitol production [191]. However, this approach seems unlikely to be beneficial, as the expression of transhydrogenase of Azotobacter vinlandii in $S$. cerevisiae augmented the glycerol and 2-oxoglutarate production and changed the intracellular ratio of $\left(\mathrm{NADH} / \mathrm{NAD}^{+}\right):\left(\mathrm{NADPH} / \mathrm{NADP}^{+}\right)$ from 17 to 35 [192], which reflected that the thermodynamic equilibrium of the transhydrogenase reaction was toward NADH production.

The $K_{m}$ value for P. stipitis XR encoded by XYL1 is 40 for NADH and 3.2 for NADPH [193]. Additionally, the NADPH formation by glucose-6-phosphate dehydrogenase occurred mainly in response to the intracellular NADPH concentrations [194]. Altogether mean that the XR of P. stipites will always prefer the use of NADPH over NADH. Conspicuously, $P$. stipitis natively produces negligible xylitol amounts; however, the engineered $S$. cerevisiae expressing the $P$. stipitis XR produces plentiful amounts of xylitol; therefore, some other unknown factors in P. stipites must be accountable for balancing the cofactor levels other than XR [80]. Recently, a recombinant strain overexpresses the endogenous GRE3 gene showed the best xylitol productivity [195], while the strains have XR from Candida tropicalis, Pichia stipites and Neurospora crassa produced xylitol with low specific productivity compared to GRE3 overexpressing strain. 


\section{Arabinose Utilization}

L-arabinose fermentation is important especially in the transformation of corn hulls to ethanol [59]. Corn fiber contains about $14 \%$ cellulose, $35 \%$ hemicelluloses and $20 \%$ starch. Precisely up to $28 \%$ of the hemicelluloses fraction is L-arabinose [196]. A widescreen of yeasts that can grow and ferment L-arabinose directly proved that four strains (Candida sp. YB-2248, C. succiphila, C. auringiensis and Ambrosiozyma monospora) are able to produce roughly $4.1 \mathrm{~g} / \mathrm{L}$ of ethanol [197]. For the first time, it was demonstrated that the yeasts were able to ferment directly L-arabinose into ethanol; however, the fermentation rates were quite very slow (Figure 2). The fermentation pathways for both D-arabinose and L-arabinose metabolism are diverse in yeasts. The $P$. stipitis natively is unable to ferment L-arabinose; however, it can grow slowly on that sugar. In 2000, it was demonstrated that a $P$. stipitis mutant was unable to grow on L-arabinose, but had the capability to metabolize D-arabinose [198]. The growth on L-arabinose was restored with complementation of that mutant with XYL2. This indicates that the metabolism of L-arabinose pathway in P. stipitis is similar to the utilization pathway of Aspergillus niger [199].

Our knowledge about uptake activity of L-arabinose by yeasts is relatively low. In S. cerevisiae, the uptake of L-arabinose appears to be mediated by the GAL2 transporter, as the L-arabinose structurally is analogous to D-galactose [200]. In C. shehatae, a proton symport seems to mediate the L-arabinose uptake [201]. Besides, D-arabinitol dehydrogenase, which has a role in another pathway, links D-xylulose to D-ribulose metabolism [172,202].

The utilization of L-arabinose in fungi occurs by five enzymes, aldose reductase (xylose reductase), L-arabinitol 4-dehydrogenase (lad1) [203], L-xylulose reductase (lxr1) [204], xylitol dehydrogenase, and D-xylulokinase. In 2003, Richard and coworkers engineered S. cerevisiae strain to utilize and ferment with very slow rate the L-arabinose into bioethanol by expressing XKS1, XYL1 and XYL2 with L-arabinitol 4-dehydrogenase and L-xylulose reductase [193]. The ethanol production yield was about $0.1 \mathrm{~g}$ per $4 \mathrm{~g}$ of cells under $70 \mathrm{~h}$ of an anaerobic fermentation. Under aerobic environments, the ethanol production would be possibly re-assimilated again.

Moreover, another engineered S. cerevisiae strain which expressed araA (encodes for Bacillus subtilis L-arabinose isomerase), $\operatorname{araB}$, and $\operatorname{araD}$ (encodes for L-arabinose metabolism in E. coli), beside the expression of GAL2 of $S$. cerevisiae, could slowly grow on L-arabinose, after more than eight days of cultivation with a doubling time of about eight hours [205]. This engineered stain was able to ferment L-arabinose slowly to produce about $0.08 \mathrm{~g}$ ethanol $/ \mathrm{g}$ biomass per hour. The ability to ferment L-arabinose arose due to two mutational events; the first was in S. cerevisiae genome, which increased the expression of the transaldolase, while the second mutation was identified in the expressed E. coli L-ribulokinase which in turn lowered the affinity to L-ribulose. Introducing the XI and XR-XDH metabolic pathways of D-xylose to obtain D-glucose, D-xylose, and L-arabinose co-fermenting strain resulted in a strain that has a capacity to display a simultaneous co-utilization of D-xylose and L-arabinose with similar consumption rates, while the D-glucose metabolic capacity was constant and did not decreased. Therefore, this engineered strain could be a useful choice for bioethanol production [206].

\section{Factors Enhancing the Productivity of Bioethanol}

There are diverse of physical factors that have an impact on the production of bioethanol, e.g., fermentation time, inoculum size, agitation rate, temperature, $\mathrm{pH}$, and sugar concentration [207]. For example, the low value of $\mathrm{pH}$ and toxicity of chemicals are known as a source of stress and cause inhibition for the growth and production of the yeast cells, which come from pretreatment of lignocellulose with the thermo-chemical method. Furthermore, microorganisms that have the capability to survive during the harsh conditions of bioethanol production from lignocellulose are promising strains for the accomplishment the fermentation processes. There are two sources for retrieving these strains, either isolating from the environment, which has optimum conditions for evolving the desirable characters or by genetic manipulation using model organisms like S. cerevisiae [208]. 
The undesired temperatures for the microbial growth, has also an inhibitory effect on bioethanol production [209]. The optimum temperature for growth of free cells of S. cerevisiae is about $30^{\circ} \mathrm{C}$, whereas the optimum temperature for the immobilized cells is slightly higher due to its capacity to transfer heat from surface to inside the cells [210]. Additionally, enzymes that coordinate fermentation process and microbial activity are susceptible to an elevated temperature that denatures the tertiary structure and inactivates the enzymes [211]. So, the temperature is a central factor in the fermentation process.

The concentration of sugar has a prominent function in the fermentation process that augments the concentration to some extent affecting positively on the bioethanol production, but the excessive addition of sugar causes constant rate of fermentation. In general, the optimum concentration of sugars for the ultimate production of ethanol is $150 \mathrm{~g} / \mathrm{L}$ [207].

The value of $\mathrm{pH}$ is considered as a major player in the fermentation process and ethanol production, as it has a remarkable impact on the growth of yeast, fermentation rate, by-product formation, and contamination of bacterial culture [207]. Furthermore, the optimum value of $\mathrm{pH}$ for the growth of the yeast between 2.75-4.25. S. cerevisiae demands $\mathrm{pH}$ value in the range of 4.0-5.0 for maximum ethanol production [212]. Extended incubation time is necessary when the value of $\mathrm{pH}$ is lower than 4.0; however, the production of ethanol is not significantly changed [213]. The low value of $\mathrm{pH}$ and toxicity of chemicals are known as a source of stress and cause inhibition for the growth and production of the yeast cells that come from pretreatment of lignocellulose with thermo-chemical method. Furthermore, microorganisms which have the capability to survive during the harsh conditions of bioethanol production from lignocellulose, are promising strains for accomplishment the fermentation processes. There are two sources for receiving these strains, either isolating from the environment which has optimum conditions for evolving the desirable characters or by genetic manipulation using model organisms like S. cerevisiae [208].

The fermentation period has a salient role in the process of ethanol production. Short fermentation time is one of the known reasons for the scanty ethanol production because of inappropriate growth of microbes. On the other hand, increasing the time of fermentation has a harmful influence on the growth of microbes because of increasing concentration of ethanol in the fermentation medium [207].

The rate of Agitation grips the permeability of nutrients from the fermentation medium to the intracellular cell. The higher concentration of ethanol produced comes from the greater rate of agitation. Additionally, it boosts the consumption of sugar and minimizes the repression of ethanol production. The optimum rate of agitation rate for maximum ethanol production and fermentation process by the yeast is in range of 150-200 rpm. Excessive rate of agitation has a negative impact on production of smooth ethanol, as well as; it counts as a reason to reduce the metabolic activities of the cells [207].

The concentration of Inoculum does not have a considerable impact on the ethanol production, but it significantly consumes the sugar content and production of ethanol in fermentation broth [214]. The production of ethanol was seen to be increased by increasing the cell density in range of $1 \times 10^{4}$ to $1 \times 10^{7}$ cells per $\mathrm{ml}$ of fermented broth counted as one of the best conditions for maximum ethanol production and fermentation processes, however there was neglected production of ethanol when the density of the cells is between $10^{7}$ and $10^{8}$ cells per $\mathrm{ml}$ due to increasing the rapid consumption of sugars into ethanol [207].

\section{Factors Prohibiting the Bioethanol Production from Lignocellulose}

Lignocellulose is composed of a complex structure formed from diverse polymers of cellulose, carbohydrates, and hemicellulose encompassed by the polymer of lignin and the phenolic compounds. Once the lignocellulose has been divided into small pieces, thermo-chemical treatment is considered as the main step of pretreatment of lignocellulose, because it is a substantial step for the hydrolysis of lignocellulose material into fermentable sugars. After this step, the lignocellulose materials become dissolvable in the liquid media that consists of formic, acetic and levulinic acids, as well as phenolic and furans compounds that formed during pretreatment step [215]. Since all of the released chemical 
compounds had a negative impact on the growth of yeast, bioethanol production and fermentation processes at all [216], alot of endeavors have been exerted to obviate the production of these harmful chemical compounds [4]. An alternative way for overcoming this obstacle is to minimize their concentrations by different application method of detoxification [215], but more procedures have a negative influence on the balance of energy and increase the cost of product which makes it unavailable for application in all conditions [3]. Whatever the method being applied for the hydrolysis process, a high concentration of sugar in the solution should take into consideration. Approximately $416 \mathrm{~g}$ of pretreated lignocellulosic material containing around $60 \%$ of fermentable sugars will be required to have these required concentrations. The final products may hold a large percentage of toxic materials, as well as enhance the quantities of insoluble fraction of cellulose and lignin. Furthermore, when the cellulose fermentation and scarification are implemented together, this could inhibit the yeast enzymatic activity and cell growth [4]. Yeast cells display toxic compounds and high concentration of osmolarity when the saccharification and fermentation occurred. At moderate conditions, the formation of toxic compounds and disruption of lignocellulose are reduced by the influence of the hydrolysis of thermo-chemical compounds [4], keeping the polymers of hemicellulose and cellulose intact for the hydrolysis with cellulosic enzymes. Fluctuations in the rate of temperature and solid loadings have a great impact on the process of saccharification [4]. Most of the commercial enzymes have optimal increasing temperatures above $45^{\circ} \mathrm{C}$ is the optimum for the activity of the most commercial enzymes, which have an important role in the industrial processing, as increasing the temperature is very useful for industrial application because it helps in minimizing the contamination. In the meantime, increasing the temperature negatively affects the growth of yeasts, which leads to shortening the process of saccharification and fermentation. To sum up, a lot of factors originate from the production of toxic compounds that inhibit the function of $S$. cerevisiae during the fermentation processes, such as, low $\mathrm{pH}$ and different concentrations of sugars.

\section{Conclusions}

Microbial strains have their own system of gene expression and metabolic processes that have been confirmed to enhance the effectiveness of the fermentation processes and to outdo the spontaneous inconstancy of the natural environmental conditions [198]. Although, the softness of the genetic system of some model organisms gives us the best chance for the genetic manipulation for acquiring new required genes/features or knocking out/down other undesired genes.

The fermentation by microbial organism provides the feasible way for conversion the disaccharides and monosaccharides to ethanol [13]. P. stipitis and S. cerevisiae are one of the most promising model organisms in microbiological fermentation (Figure 4). P. stipitis produces approximately $0.5 \mathrm{~g}$ of ethanol for each gram of fermented substrate [199]. It has the ability for bioethanol production by using different surge sources of the lignocellulosic material. P. stipites arise the high potential advantage for commercial, economical, and ecological applications in the near future. However, the S. cerevisiae is still the most potential candidate of microbial fermentation due to its ability to bioconversion of three out of the five sugars from lignocellulosic feedstocks, which, in turn, produces a high amount of ethanol. The yeast is a great exemplary field for fermentation processes, which could rescue our future with depletion of the petroleum oil. 


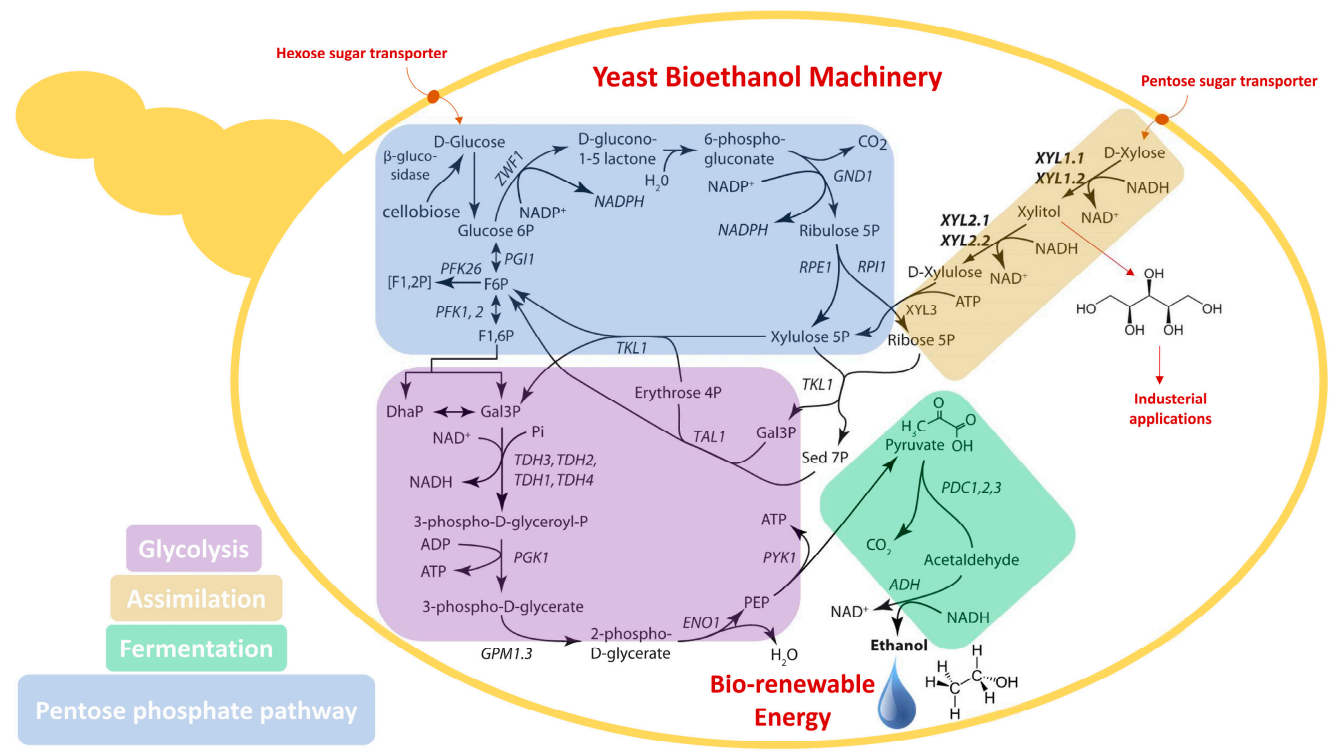

Figure 4. Model for bioethanol production using yeast fermentation machinery.

Acknowledgments: Khaled A. Selim received the Parwon scholarship at Institute for Microbial and Biochemical Technology, Forest Products Laboratory, USDA. Additionally, Khaled A. Selim and Dina E. El-Ghwas would like to thank Ahmed El-Diwany (National Research Centre), Thomas Jeffries (University of Wisconsin Madison), Laura Willis (Forest Products Laboratory, USDA) and Katerina Peros for the invaluable and unlimited support received during the practical work of the research project and writing this manuscript.

Author Contributions: Khaled A. Selim, Dina E. El-Ghwas, Mohamed I. Abdelwahab Hassan did extensive literature review and wrote the manuscript. Khaled A. Selim, Dina E. El-Ghwas, Mohamed I. Abdelwahab Hassan and Saadia M. Easa corrected the revised draft.

Conflicts of Interest: The authors declare no conflict of interest.

\section{References}

1. Kiran, B.; Kumar, R.; Deshmukh, D. Perspectives of microalgal biofuels as a renewable source of energy. Energy Convers. Manag. 2014, 88, 1228-1244. [CrossRef]

2. Xie, D. Integrating Cellular and Bioprocess Engineering in the Non-Conventional Yeast Yarrowia lipolytica for Biodiesel Production. Front. Bioeng. Biotechnol. 2017, 5, 65. [CrossRef] [PubMed]

3. Caspeta, L.; Buijs, N.A.A.; Nielsen, J. The role of biofuels in the future energy supply. Energy Environ. Sci. 2013, 6, 1077-1082. [CrossRef]

4. Caspeta, L.; Caro-Bermúdez, M.A.; Ponce-Noyola, T.; Martinez, A. Enzymatic hydrolysis at high-solids loadings for the conversion of agave bagasse to fuel ethanol. Appl. Energy 2014, 113, 277-286. [CrossRef]

5. Rouhollah, H.; Iraj, N.; Giti, E.; Sorah, A. Mixed sugar fermentation by Pichia stipitis, Saccharomyces cerevisiae and an isolated xylose fermenting Kluyveromyces marxinus and their co-culture. Afr. J. Biotechnol. 2007, 6, 1110-1114.

6. Fromanger, R.; Guillouet, S.E.; Uribelarrea, J.L.; Molina-Jouve, C.; Cameleyre, X. Effect of controlled oxygen limitation on Candida shehatae physiology for ethanol production from xylose and glucose. J. Ind. Microbiol. Biotechnol. 2010, 37, 437-445. [CrossRef] [PubMed]

7. Soccol, C.; Vanderberghel, L.; Medeiros, A.; Karp, S.; Buckeridge, M.; Ramos, L.P.; Pitarelo, A.P.; Ferreira-Leito, V.; Gottschalk, L.; Ferrara, M.A.; et al. Bioethanol from lignocelluloses: Status and perspectives in Brazil. Bioresour. Technol. 2010, 101, 4820-4825. [CrossRef] [PubMed]

8. Mosier, N.; Wyman, C.; Dale, B.; Elander, R.; Lee, Y.Y.; Ladisch, M. Features of promising technologies for treatment of lignocellulosic biomass. Bioresour. Technol. 2005, 96, 673-686. [CrossRef] [PubMed] 
9. Zaldivar, J.; Martinez, A.; Ingram, L.O. Effect of alcohol compounds found in hemicellulose hydrolysate on the growth and fermentation of ethanologenic Escherichia coli. Biotechnol. Bioeng. 2000, 68, 524-530. [CrossRef]

10. Fu, N.; Peires, P.; Markham, J.; Bayor, J. A novel co-culture process with Zymomonas mobilis and Pichia stipitis for efficient ethanol production on glucose/xylose mixtures. Enzyme Microb. Technol. 2009, 45, 210-217. [CrossRef]

11. Van Vleet, J.H.; Jeffries, T.W. Yeast metabolic engineering for hemicellulosic ethanol production. Curr. Opin. Biotechnol. 2009, 20, 300-306. [CrossRef] [PubMed]

12. Aristidou, A.; Penttila, M. Metabolic engineering applications to renewable resource utilization. Curr. Opin. Biotechnol. 2000, 11, 187-198. [CrossRef]

13. Van Zyl, W.; Lynd, L.; den Hann, R.; McBride, J. Consolidated bioprocessing for bioethanol production using Saccharomyces cerevisiae. Adv. Biochem. Eng. Biotechnol. 2007, 108, 205-235. [PubMed]

14. Hahn-Hägerdal, B.; Karhumaa, K.; Fonseca, C.; Martins, S.; Gorwa-Grauslund, M.F. Towards industrial pentose-fermenting yeast strains. Appl. Microbiol. Biotechnol. 2007, 74, 937-953. [CrossRef] [PubMed]

15. Jin, Y.S.; Cate, J.H. Metabolic engineering of yeast for lignocellulosic biofuel production. Curr. Opin. Chem. Biol. 2017, 41, 99-106. [CrossRef] [PubMed]

16. Azhar, S.H.M.; Abdulla, R.; Jambo, S.A.; Marbawi, H.; Gansau, J.A.; Faik, A.A.M.; Rodrigues, K.F. Yeasts in sustainable bioethanol production: A review. Biochem. Biophys. Rep. 2017, 10, 52-61.

17. Van Maris, A.J.; Abbott, D.A.; Bellissimi, E.; van den Brink, J.; Kuyper, M.; Luttik, M.A.; Wisselink, H.W.; Scheffers, W.A.; van Dijken, J.P.; Pronk, J.T. Alcoholic fermentation of carbon sources in biomass hydrolysates by Saccharomyces cerevisiae: Current status. Antonie Van Leeuwenhoek 2006, 90, 391-418. [CrossRef] [PubMed]

18. Bader, J.; Mast-Gerlach, E.; Popovic, M.K.; Bajpai, R.; Stahl, U. Relevance of microbial coculture fermentations in biotechnology. J. Appl. Microbiol. 2009, 109, 371-387. [CrossRef] [PubMed]

19. Grootjen, D.R.J.; Vleesenbeek, R.M.; Windmeijer, G.A.; van der Lans, R.G.J.M.; Luyben, K.C.A. A flocculating strain of Pichia stipitis for the conversion of glucose/xylose mixtures. Enzyme Microb. Technol. 1991, 13, 734-739. [CrossRef]

20. Fu, N.; Peiris, P. Co-fermentation of a mixture of glucose and xylose to ethanol by Zymomonas mobilis and Pachysolen tannophilus. World J. Microbiol. Biotechnol. 2008, 24, 1091-1097. [CrossRef]

21. Weir, P.M. The ecology of Zymomonas: A review. Folia Microbiol. 2016, 61, 385-392. [CrossRef] [PubMed]

22. Palmqvist, E.; Hahn-Hagerdal, B. Fermentation of lignocellulosic hydrolysates I: Inhibition and detoxification. Bioresour. Technol. 2000, 74, 17-24. [CrossRef]

23. Klinke, H.B.; Thomsen, A.; Ahring, B. Inhibition of ethanol-producing yeast and bacteria by degradation products produced during pre-treatment of biomass. Appl. Microbiol. Biotechnol. 2004, 66, 10-26. [CrossRef] [PubMed]

24. Aguilar, R.; Ramrez, J.A.; Garrote, G.; Vzquez, M. Kinetic study of the acid hydrolysis of sugar cane bagasse. J. Food Eng. 2002, 55, 309-318. [CrossRef]

25. Larsson, S.; Palmqvist, E.; Hahn-Hgerdal, B.; Tengborg, C.; Stenberg, K.; Zacchi, G.; Nilvebrant, N.O. The generation of fermentation inhibitors during dilute acid hydrolysis of softwood. Enzyme Microb. Technol. 1999, 24, 151-159. [CrossRef]

26. Zaldivar, J.; Nielsen, J.; Olsson, L. Fuel ethanol production from lignocellulose: A challenge for metabolic engineering and process integration. Appl. Microbiol. Biotechnol. 2001, 56, 17-34. [CrossRef] [PubMed]

27. Keating, J.D.; Panganiban, C.; Mansfield, S.D. Tolerance and adaptation of ethanologenic yeasts to lignocellulosic inhibitory compounds. Biotechnol. Bioeng. 2006, 93, 1196-1206. [CrossRef] [PubMed]

28. Skoog, K.; Hähn-Hagerdal, B. Xylose fermentation. Enzyme Microb. Technol. 1988, 10, 66-80. [CrossRef]

29. Schneider, H. Conversion of Pentoses to Ethanol by Yeasts and Fungi. Crit. Rev. Biotechnol. 1989, 9, 1-40. [CrossRef] [PubMed]

30. Mishra, P.; Singh, A. Microbial Pentose Utilization. Adv. Appl. Microbiol. 1993, 39, 91-152. [PubMed]

31. Maleszka, R.; Schneider, H. Fermentation of D-xylose, xylitol, and D-xylulose by yeasts. Can. J. Microbiol. 1982, 28, 360-363. [CrossRef] [PubMed]

32. Slininger, P.J.; Bothast, R.J.; van Cawenberge, J.E.; Kurtzman, C.P. Conversion of D-xylose to ethanol by the yeast Pachysolen tannophilus. Biotechnol. Bioeng. 1982, 24, 371-384. [CrossRef] [PubMed] 
33. Latimer, L.N.; Dueber, J.E. Iterative Optimization of Xylose Catabolism in Saccharomyces cerevisiae Using Combinatorial Expression Tuning. Biotechnol. Bioeng. 2017, 114, 1301-1309. [CrossRef] [PubMed]

34. Bailey, J.E. Toward a science of metabolic engineering. Science 1991, 252, 1668-1675. [CrossRef] [PubMed]

35. Stephanopoulos, G.; Vallino, J.J. Network rigidity and metabolic engineering in metabolite overproduction. Science 1991, 252, 1675-1681. [CrossRef]

36. Stephanopoulos, G.; Nielsen, J.; Aristidou, A. Metabolic Engineering; Academic Press: San Diego, CA, USA, 1998.

37. Feist, A.M.; Henry, C.S.; Reed, J.L.; Krummenacker, M.; Joyce, A.R.; Karp, P.D.; Broadbelt, L.J.; Hatzimanikatis, V.; Palsson, B.Ø. A genomescale metabolic reconstruction for Escherichia coli K-12 MG1655 that accounts for 1260 ORFs and thermodynamic information. Mol. Syst. Biol. 2007, 3, 121. [CrossRef] [PubMed]

38. Keseler, I.M.; Bonavides-Martínez, C.; Collado-Vides, J.; Gama-Castro, S.; Gunsalus, R.P.; Johnson, D.A.; Krummenacker, M.; Nolan, L.M.; Paley, S.; Paulsen, I.T.; et al. EcoCyc: A comprehensive view of Escherichia coli biology. Nucleic Acids Res. 2009, 37, D464-D470. [CrossRef] [PubMed]

39. Endy, D. Foundations for engineering biology. Nature 2005, 438, 449-453. [CrossRef] [PubMed]

40. Piontek, M.; Hagedorn, J.; Hollenberg, C.P.; Gellissen, G.; Strasser, A.W. Two novel expression systems based on the yeasts Schwanniomyces occidentalis and Pichia stipitis. Appl. Microbiol. Biotechnol. 1998, 50, 331-338. [CrossRef] [PubMed]

41. Williams, E.J.; Bowles, D.J. Coexpression of neighboring genes in the genome of Arabidopsis thaliana. Genome Res. 2004, 14, 1060-1067. [CrossRef] [PubMed]

42. Cohen, B.A.; Mitra, R.D.; Hughes, J.D.; Church, G.M. A computational analysis of whole-genome expression data reveals chromosomal domains of gene expression. Nat. Genet. 2000, 26, 183-186. [CrossRef] [PubMed]

43. Lercher, M.J.; Urrutia, A.O.; Hurst, L.D. Clustering of housekeeping genes provides a unified model of gene order in the human genome. Nat. Genet. 2002, 31, 180-183. [CrossRef] [PubMed]

44. Lercher, M.J.; Blumenthal, T.; Hurst, L.D. Co. expression of neighboring genes in Caenorhabditis elegans is mostly due to operons and duplicate genes. Genome Res. 2003, 13, 238-243. [CrossRef] [PubMed]

45. Qi, X.; Bakht, S.; Leggett, M.; Maxwell, C.; Melton, R.; Osbourn, A. A gene cluster for secondary metabolism in oat: implications for the evolution of metabolic diversity in plants. Proc. Natl. Acad. Sci. USA. 2004, 101, 8233-8238. [CrossRef] [PubMed]

46. Hesberg, C.; Hansch, R.; Mendel, R.R.; Bittner, F. Tandem orientation of duplicated xanthine dehydrogenase genes from Arabidopsis thaliana: Differential gene expression and enzyme activities. J. Bio. Chem. 2004, 279, 13547-13554. [CrossRef] [PubMed]

47. Tsuchiya, T.; Takesawa, T.; Kanzaki, H.; Nakamura, I. Genomic structure and differential expression of two tandem-arranged GSTZ genes in rice. Gene 2004, 335, 141-149. [CrossRef] [PubMed]

48. Prescott, E.M.; Proudfoot, N.J. Transcriptional collision between convergent genes in budding yeast. Proc. Natl. Acad. Sci. USA 2002, 99, 8796-8801. [CrossRef] [PubMed]

49. Valerius, O.; Brendel, C.; Duvel, K.; Braus, G.H. Multiple factors prevent transcriptional interference at the yeast ARO4-HIS7 locus. J. Biol. Chem. 2002, 277, 21440-21445. [CrossRef] [PubMed]

50. Springer, C.; Valerius, O.; Strittmatter, A.; Braus, G.H. The adjacent yeast genes ARO4 and HIS7 carry no intergenic region. J. Biol. Chem. 1997, 272, 26318-26324. [CrossRef] [PubMed]

51. Martens, J.A.; Laprade, L.; Winston, F. Intergenic transcription is required to repress the Saccharomyces cerevisiae SER3 gene. Nature 2004, 429, 571-574. [CrossRef] [PubMed]

52. Schmitt, S.; Paro, R. Gene regulation: A reason for reading nonsense. Nature 2004, 429, 510-511. [CrossRef] [PubMed]

53. Marin, A.; Wang, M.; Gutierrez, G. Short-range compositional correlation in the yeast genome depends on transcriptional orientation. Gene 2004, 333, 151-155. [CrossRef] [PubMed]

54. McMillan, J.D. Bioethanol production: Status and prospects. Renew. Energy 1997, 10, 295-302. [CrossRef]

55. Claassen, P.A.M.; van Lier, J.B.; Lopez Contreras, A.M.; van Niel, E.W.J.; Sijtsma, L.; Stams, A.J.M.; de Vries, S.S.; Weusthuis, R.A. Utilization of biomass for the supply of energy carriers. Appl. Microbiol. Biotechnol. 1999, 52, 741-755. [CrossRef]

56. Wyman, C.E. Biomass ethanol: Technical progress, opportunities, and commercial challenges. Annu. Rev. Energy Environ. 1999, 24, 189-226. [CrossRef]

57. Kheshgi, H.S.; Prince, R.C.; Marland, G. The potential of biomass fuels in the context of global climate change: Focus on transportation fuels. Annu. Rev. Energy Environ. 2000, 25, 199-244. [CrossRef] 
58. Roca, C.; Olsson, L. Increasing ethanol productivity during xylose fermentation by cell recycling of recombinant Saccharomyces cerevisiae. Appl. Microbiol. Biotechnol. 2003, 60, 560-563. [CrossRef] [PubMed]

59. Saha, B.C.; Dien, B.S.; Bothast, R.J. Fuel ethanol production from corn fiber-Current status and technical prospects. Appl. Biochem. Biotechnol. 1998, 70, 115-125. [CrossRef]

60. Saha, B.C.; Bothast, R.J. Pretreatment and enzymatic saccharification of corn fiber. Appl. Biochem. Biotechnol. 1999, 76, 65-77. [CrossRef]

61. Hinmann, N.D.; Wright, J.D.; Hoagland, W.; Wyman, C.E. Xylose fermentation-An economic analysis. Appl. Biochem. Biotechnol. 1989, 20, 391-401. [CrossRef]

62. Olsson, L.; Hahn-Hägerdal, B. Fermentation of lignocellulosic hydrolysates for ethanol production. Enzyme Microb. Technol. 1996, 18, 312-331. [CrossRef]

63. Smil, V. Crop residues: Agriculture's largest harvest-Crop residues incorporate more than half of the world agricultural phytomass. Bioscience 1999, 49, 299-308. [CrossRef]

64. Lynd, L.R. Overview and evaluation of fuel ethanol from cellulosic biomass: Technology, economics, the environment, and policy. Annu. Rev. Energy Environ. 1996, 21, 403-465. [CrossRef]

65. Pettersen, R.C. The chemical composition of wood. Adv. Chem. Ser. 1984, 1984, 57-126.

66. Hespell, R.B. Extraction and characterization of hemicelluloses from the corn fiber produced by corn wet-milling processes. J. Agric. Food Chem. 1998, 46, 2615-2619. [CrossRef]

67. Lawford, H.G.; Rousseau, J.D. Production of ethanol from pulpmill hardwood and softwood spent sulfite liquors by genetically engineered Escherichia coli. Appl. Biochem. Biotechnol. 1993, 39, 667-685. [CrossRef] [PubMed]

68. Chen, R.F.; Wu, Z.W.; Lee, Y.Y. Shrinking-bed model for percolation process applied to dilute-acid pretreatment hydrolysis of cellulosic biomass. Appl. Biochem. Biotechnol. 1998, 70, 37-49. [CrossRef]

69. Kim, K.H.; Tucker, M.P.; Keller, F.A.; Aden, A.; Nguyen, Q.A. Continuous countercurrent extraction of hemicellulose from pretreated wood residues. Appl. Biochem. Biotechnol. 2001, 91-93, 253-267. [CrossRef]

70. Wang, P.Y.; Schneider, H. Growth of yeasts on D-xylulose 1. Can. J. Microbiol. 1980, 26, 1165-1168. [CrossRef] [PubMed]

71. Wang, P.Y.; Shopsis, C.; Schneider, H. Fermentation of a pentose by yeasts. Biochem. Biophys. Res. Commun. 1980, 94, 248-254. [CrossRef]

72. Schneider, H.; Wang, P.Y.; Chan, Y.K.; Maleszka, R. Conversion of D-xylose into ethanol by the yeast Pachysolen tannophilus. Biotechnol. Lett. 1981, 3, 89-92. [CrossRef]

73. Jeffries, T.W. A comparison of Candida tropicalis and Pachysolen tannophilus for conversion of xylose to ethanol. Biotechnol. Bioeng. Symp. 1982, 12, 103-110.

74. Toivola, A.; Yarrow, D.; Bosch, E.; van den Dijken, J.P.; van Scheffers, W.A. Alcoholic fermentation of deuterium-xylose by yeasts. Appl. Environ. Microbiol. 1984, 47, 1221-1223. [PubMed]

75. Du Preez, J.C.; Boschm, M.; Prior, B.A. Xylose fermentation by Candida shehatae and Pichia stipitis-Effects of $\mathrm{pH}$, temperature and substrate concentration. Enzyme Microb. Technol. 1986, 8, 360-364. [CrossRef]

76. Jeffries, T.W.; Shi, N.Q. Genetic engineering for improved xylose fermentation by yeasts. Adv. Biochem. Eng. Biotechnol. 1999, 65, 117-161. [PubMed]

77. Hahn-Hägerdal, B.; Wahlbom, C.F.; Gardonyi, M.; Zyl, W.H.; van Cordero Otero, R.R.; Jönsson, L.J. Metabolic engineering of Saccharomyces cerevisiae for xylose utilization. Adv. Biochem. Eng. Biotechnol. 2001, 73, 53-84. [PubMed]

78. Jeffries, T.W.; Van Vleet, J.R.H. Pichia stipitis genomics, transcriptomics, and gene clusters. FEMS Yeast Res. 2009, 9, 793-807. [CrossRef] [PubMed]

79. Melake, T.; Passoth, V.; Klinner, U. Characterization of the genetic system of the xylose-fermenting yeast Pichia stipitis. Curr. Microbiol. 1996, 33, 237-242. [CrossRef] [PubMed]

80. Jeffries, T.W.; Jin, Y.S. Metabolic engineering for improved fermentation of pentoses by yeasts. Appl. Microbiol. Biot. 2004, 63, 495-509. [CrossRef] [PubMed]

81. Yang, V.W.; Marks, J.A.; Davis, B.P.; Jeffries, T.W. High efficiency transformation of Pichia stipitis based on its URA3 gene and a homologous autonomous replication sequence, ARS2. Appl. Environ. Microbol. 1994, 60, 4245-4254.

82. Lu, P.; Davis, B.P.; Hendrick, J.; Jeffries, T.W. Cloning and disruption of the beta-isopropylmalate dehydrogenase gene (LEU2) of Pichia stipitis with URA3 and recovery of the double auxotroph. Appl. Microbiol. Biot. 1998, 49, 141-146. [CrossRef] 
83. Laplaza, J.M.; Torres, B.R.; Jin, Y.S.; Jeffries, T.W. Sh ble and Cre adapted for functional genomics and metabolic engineering of Pichia stipitis. Enzyme Microb. Technol. 2006, 38, 741-747. [CrossRef]

84. Van Dijken, J.P.; van den Bosch, E.; Hermans, J.J.; de Miranda, L.R.; Scheffers, W.A. Alcoholic fermentation by 'nonfermentative' yeasts. Yeast 1986, 2, 123-127. [CrossRef] [PubMed]

85. Du Preez, J.C.; van Driessel, B.; Prior, B.A. Ethanol tolerance of Pichia stipitis and Candida shehatae strains in fed-batch cultures at controlled low dissolved-oxygen levels. Appl. Microbiol. Biot. 1989, 30, 53-58. [CrossRef]

86. Nardi, J.B.; Bee, C.M.; Miller, L.A.; Nguyen, N.H.; Suh, S.O.; Blackwell, M. Communities of microbes that inhabit the changing hindgut landscape of a subsocial beetle. Arthropod Struct. Dev. 2006, 35, 57-68. [CrossRef] [PubMed]

87. Suh, S.O.; Marshall, C.J.; McHugh, J.V.; Blackwell, M. Wood ingestion by passalid beetles in the presence of xylose fermenting gut yeasts. Mol. Ecol. 2003, 12, 3137-3145. [CrossRef] [PubMed]

88. Vaughan Martini, A.E. Comparazione dei genomi del lievito Pichia stipitis e de alcune specie imperfette affini. Ann. Fac. Agric. Univ. Perugia 1984, 38, 331-335.

89. Kurtzman, C.P. Candida shehatae-genetic diversity and phylogenetic relationships with other xylose-fermenting yeasts. Antonie van Leeuwenhoek 1990, 57, 215-222. [CrossRef] [PubMed]

90. Gupthar, A.S. Theoretical and practical aspects of ploidy estimation in Pichia stipitis. Mycol. Res. 1994, 98, 716-718. [CrossRef]

91. Hahn-H“agerdal, B.; Pamment, N. Microbial pentose metabolism. Appl. Biochem. Biotechnol. 2004, 113-116, 1207-1209.

92. Nigam, J.N. Development of xylose-fermenting yeast Pichia stipitis for ethanol production through adaptation on hardwood hemicellulose acid prehydrolysate. J. Appl. Microbiol. 2001, 90, 208-215. [CrossRef] [PubMed]

93. Nigam, J.N. Ethanol production from hardwood spent sulfite liquor using an adapted strain of Pichia stipitis. J. Ind. Microbiol. Biot. 2001, 26, 145-150. [CrossRef]

94. Lee, H.; Biely, P.; Latta, R.K.; Barbosa, M.F.S.; Schneider, H. Utilization of xylan by yeasts and its conversion to ethanol by Pichia stipitis strains. Appl. Environ. Microbiol. 1986, 52, 320-324.

95. Ozcan, S.; Kotter, P.; Ciriacy, M. Xylan-hydrolyzing enzymes of the yeast Pichia stipitis. Appl. Microbiol. Biot. 1991, 36, 190-195. [CrossRef]

96. Koivistoinen, O.M.; Hilditch, S.; Voutilainen, S.P.; Boer, H.; Penttila, M.; Richard, P. Identification in the yeast Pichia stipitis of the first L-rhamnose-1-dehydrogenase gene. FEBS J. 2008, 275, 2482-2488. [CrossRef] [PubMed]

97. Fuganti, C.; Grasselli, P.; Zucchi, G.; Allegrone, G.; Barbeni, M. On the microbial biogeneration of (R) gamma-jasmolactone. Bioorg. Med. Chem. Lett. 1993, 3, 2777-2780. [CrossRef]

98. Conceicao, G.J.A.; Moran, P.J.S.; Rodrigues, J.A.R. Highly efficient extractive biocatalysis in the asymmetric reduction of an acyclic enone by the yeast Pichia stipitis. Tetrahedron Asymmetry 2003, 14, 43-45. [CrossRef]

99. Targonski, Z. Biotransformation of lignin-related aromatic compounds by Pichia stipitis Pignal. Zbl. Mikrobiol. 1992, 147, 244-249.

100. Kim, M.S.; Chung, Y.S.; Seo, J.H.; Jo, D.H.; Park, Y.H.; Ryu, Y.W. High-yield production of xylitol from xylose by a xylitol dehydrogenase defective mutant of Pichia stipitis. J. Microbiol. Biotechnol. 2001, 11, 564-569.

101. Ilmen, M.; Koivuranta, K.; Ruohonen, L.; Suominen, P.; Penttila, M. Efficient production of L-lactic acid from xylose by Pichia stipitis. Appl. Environ. Microbiol. 2007, 73, 117-123. [CrossRef] [PubMed]

102. Liu, Z.L.; Slininger, P.J.; Gorsich, S.W. Enhanced biotransformation of furfural and hydroxymethylfurfural by newly developed ethanologenic yeast strains. Appl. Microbiol. Biot. 2005, 121, 451-460.

103. Harhangi, H.R.; Akhmanova, A.S.; Emmens, R.; van der Drift, C.; de Laat, W.T.; van Dijken, J.P.; Jetten, M.S.; Pronk, J.T.; Op den Camp, H.J. Xylose metabolism in the anaerobic fungus Piromyces sp strain E2 follows the bacterial pathway. Arch. Microbiol. 2003, 180, 134-141. [CrossRef] [PubMed]

104. Sonderegger, M.; Jeppsson, M.; Hahn-Hagerdal, B.; Sauer, U. Molecular basis for anaerobic growth of Saccharomyces cerevisiae on xylose, investigated by global gene expression and metabolic flux analysis. Appl. Environ. Microbiol. 2004, 70, 2307-2317. [CrossRef]

105. Karhumaa, K.; Hahn-Hagerdal, B.; Gorwa-Grauslund, M.F. Investigation of limiting metabolic steps in the utilization of xylose by recombinant Saccharomyces cerevisiae using metabolic engineering. Yeast 2005, 22, 359-368. [CrossRef] [PubMed] 
106. Wiedemann, B.; Boles, E.; Keller, M. Construction and optimization of pentose-fermenting yeast strains for bioethanol production. Zuckerindustrie 2006, 131, 627-631.

107. Matsushika, A.; Watanabe, S.; Kodaki, T.; Makino, K.; Sawayama, S. Bioethanol production from xylose by recombinant Saccharomyces cerevisiae expressing xylose reductase, NADP(1)-dependent xylitol dehydrogenase, and xylulokinase. J. Biosci. Bioeng. 2008, 105, 296-299. [CrossRef] [PubMed]

108. Karhumaa, K.; Sanchez, R.G.; Hahn-Hagerdal, B.; Gorwa-Grauslund, M.F. Comparison of the xylose reducta sexylitol dehydrogenase and the xylose isomerase pathways for xylose fermentation by recombinant Saccharomyces cerevisiae. Microb. Cell Fact. 2007, 6, 5. [CrossRef] [PubMed]

109. Weierstall, T.; Hollenberg, C.P.; Boles, E. Cloning and characterization of three genes (SUT1-3) encoding glucose transporters of the yeast Pichia stipitis. Mol. Microbiol. 1999, 31, 871-883. [CrossRef] [PubMed]

110. Saloheimo, A.; Rauta, J.; Stasyk, O.; Sibirny, A.; Penttilä, M.; Ruohonen, L. Xylose transport studies with xylose-utilizing Saccharomyces cerevisiae strains expressing heterologous and homologous permeases. Appl. Microbiol. Biotechnol. 2007, 74, 1041-1052. [CrossRef] [PubMed]

111. Hector, R.E.; Qureshi, N.; Hughes, S.R.; Cotta, M.A. Expression of a heterologous xylose transporter in a Saccharomyces cerevisiae strain engineered to utilize xylose improves aerobic xylose consumption. Appl. Microbiol. Biotechnol. 2008, 80, 675-684. [CrossRef] [PubMed]

112. Leandro, M.J.; Spencer-Martins, I.; Goncalves, P. The expression in Saccharomyces cerevisiae of a glucose/xylose symporter from Candida intermedia is affected by the presence of a glucose/xylose facilitator. Microbiology 2008, 154, 1646-1655. [CrossRef] [PubMed]

113. Jin, Y.S.; Laplaza, J.M.; Jeffries, T.W. Saccharomyces cerevisiae engineered for xylose metabolism exhibits a respiratory response. Appl. Environ. Microbiol. 2004, 70, 6816-6825. [CrossRef] [PubMed]

114. Passoth, V.; Zimmermann, M.; Klinner, U. Peculiarities of the regulation of fermentation and respiration in the crabtreenegative, xylose-fermenting yeast Pichia stipitis. Appl. Biochem. Biotechnol. 1996, 57-58, 201-212. [CrossRef]

115. Passoth, V.; Cohn, M.; Schafer, B.; Hahn-Hagerdal, B.; Klinner, U. Molecular analysis of the hypoxia induced ADH2- promoter in the respiratory yeast Pichia stipitis. Yeast 2003, 20, 39-51. [CrossRef] [PubMed]

116. Passoth, V.; Cohn, M.; Schafer, B.; Hahn-Hagerdal, B.; Klinner, U. Analysis of the hypoxia-induced ADH2 promoter of the respiratory yeast Pichia stipitis reveals a new mechanism for sensing of oxygen limitation in yeast. Yeast 2003, 20, 39-51. [CrossRef] [PubMed]

117. Klinner, U.; Fluthgraf, S.; Freese, S.; Passoth, V. Aerobic induction of respiro-fermentative growth by decreasing oxygen tensions in the respiratory yeast Pichia stipitis. Appl. Microbiol. Biot. 2005, 67, 247-253. [CrossRef] [PubMed]

118. Auer, L.; Lazuka, A.; Sillam-Dussès, D.; Miambi, E.; O’Donohue, M.; Hernandez-Raquet, G. Uncovering the Potential of Termite Gut Microbiome for Lignocellulose Bioconversion in Anaerobic Batch Bioreactors. Front. Microbiol. 2017, 8, 2623. [CrossRef] [PubMed]

119. Kong, W.; Fu, X.; Wang, L.; Alhujaily, A.; Zhang, J.; Ma, F.; Zhang, X.; Yu, H. A novel and efficient fungal delignification strategy based on versatile peroxidase for lignocellulose bioconversion. Biotechnol. Biofuels 2017, 10, 218. [CrossRef] [PubMed]

120. Kowalik, M.A.; Columbano, A.; Perra, A. Emerging Role of the Pentose Phosphate Pathway in Hepatocellular Carcinoma. Front. Oncol. 2017, 7, 87. [CrossRef] [PubMed]

121. Jeffries, T.W. Engineering yeasts for xylose metabolism. Curr. Opin. Biotechnol. 2006, 17, 320-326. [CrossRef] [PubMed]

122. Kötter, P.; Ciriacy, M. Xylose fermentation by Saccharomyces cerevisiae. Appl. Microbiol. Biotechnol. 1993, 38, 776-783. [CrossRef]

123. Metzger, M.H.; Hollenberg, C.P. Isolation and characterization of the Pichia stipitis transketolase gene and expression in a xylose-utilising Saccharomyces cerevisiae transformant. Appl. Microbiol. Biotechnol. 1994, 42, 319-325. [CrossRef] [PubMed]

124. Walfridsson, M.; Hallborn, J.; Penttilä, M.; Keränen, S.; Hahn-Hägerdal, B. Xylose-metabolizing Saccharomyces cerevisiae strains overexpressing the TKL1 and TAL1 genes encoding the pentose phosphate pathway enzymes transketolase and transaldolase. Appl. Environ. Microbiol. 1995, 61, 4184-4190. [PubMed]

125. Bao, X.; Gao, D.; Qu, Y.; Wang, Z.; Walfridssion, M.; Hahn-Hägerdal, B. Effect on product formation in recombinant Saccharomyces cerevisiae strains expressing different levels of xylose metabolic genes. Chin. J. Biotechnol. 1997, 13, 225-231. [PubMed] 
126. Meinander, N.Q.; Boels, I.; Hahn-Hägerdal, B. Fermentation of xylose/glucose mixtures by metabolically engineered Saccharomyces cerevisiae strains expressing XYL1 and XYL2 from Pichia stipitis with and without overexpression of TAL1. Bioresour. Technol. 1999, 68, 79-87. [CrossRef]

127. Hawkins, P.J.; Ordonez, P.A.; Oresnik, I.J. Characterization of mutants that affect the non-oxidative pentose phosphate pathway in Sinorhizobium meliloti. J. Bacteriol. 2017. [CrossRef]

128. Lee, M.; Henriëtte, J.; Rozeboom, H.J.; de Waal, P.P.; de Jong, R.M.; Dudek, H.M.; Janssen, D.B. Metal Dependence of the Xylose Isomerase from Piromyces sp. E2 Explored by Activity Profiling and Protein Crystallography. Biochemistry 2017, 56, 5991-6005. [PubMed]

129. Temer, B.; dos Santos, L.V.; Negri, V.A.; Galhardo, J.P.; Magalhães, P.H.M.; José, J.; Marschalk, C.; Corrêa, T.L.R.; Carazzolle, M.F.; Pereira, G.A.G. Conversion of an inactive xylose isomerase into a functional enzyme by co-expression of GroEL-GroES chaperonins in Saccharomyces cerevisiae. BMC Biotechnol. 2017, 17, 71. [CrossRef] [PubMed]

130. Smith, C.A.; Rangarajan, M.; Hartley, B.S. D-Xylose (D-glucose) isomerase from Arthrobacter strain NRRL B3728. Purification and properties. Biochem. J. 1991, 277, 255-261. [PubMed]

131. Walfridsson, M.; Bao, X.; Anderlund, M.; Lilius, G.; Bulow, L.; Hahn-Hägerdal, B. Ethanolic fermentation of xylose with Saccharomyces cerevisiae harboring the Thermus thermophilus xylA gene, which expresses an active xylose (glucose) isomerase. Appl. Environ. Microbiol. 1996, 62, 4648-4651. [PubMed]

132. Träff, K.L.; Otero Cordero, R.R.; van Zyl, W.H.; Hahn-Hägerdal, B. Deletion of the GRE3aldose reductase gene and its influence on xylose metabolism in recombinant strains of Saccharomyces cerevisiae expressing the xylA and XKS1 genes. Appl. Environ. Microbiol. 2001, 67, 5668-5674. [CrossRef] [PubMed]

133. Lönn, A.; Gardonyi, M.; Zyl, W.V.; Hahn-Hägerdal, B.; Otero, R.C. Cold adaptation of xylose isomerase from Thermus thermophilus through random PCR mutagenesis. Gene cloning and protein characterization. Eur. J. Biochem. 2002, 269, 157-163. [CrossRef] [PubMed]

134. Kuyper, M.; Harhangi, H.R.; Stave, A.K.; Winkler, A.A.; Jetten, M.S.M.; De Laat, W.T.A.M.; Den Ridder, J.J.J.; Op den Camp, H.J.M.; Van Dijken, J.P.; Pronk, J.T. High-level functional expression of a fungal xylose isomerase: The key to efficient ethanolic fermentation of xylose by Saccharomyces cerevisiae? FEMS Yeast Res. 2003, 4, 69-78. [CrossRef]

135. Jeffries, T.W. Emerging technology for fermenting D-xylose. Trends Biotechnol. 1985, 3, 208-212. [CrossRef]

136. Verhoeven, M.D.; Lee, M.; Kamoen, L.; van den Broek, M.; Janssen, D.B.; Daran, J.G.; Antonius, J.A.; van Maris, A.J.A.; Pronk, J.T. Mutations in PMR1stimulate xylose isomerase activity and anaerobic growth on xylose of engineered Saccharomyces cerevisiae by influencing manganese homeostasis. Sci. Rep. 2017, 7, 46155. [CrossRef] [PubMed]

137. Wijsman, M.R.; Bruinenberg, P.M.; Van Dijken, J.P.; Scheffers, W.A. Incapacity for anaerobic growth in xylose-fermenting yeasts. Antonie Van Leeuwenhoek 1985, 51, 563-564. [CrossRef]

138. Hallborn, J.; Gorwa, M.F.; Meinander, N. The influence of cosubstrate and aeration on xylitol formation by recombinant Saccharomyces cerevisiae expressing the XYL1 gene. Appl. Microbiol. Biotechnol. 1994, 42, 326-333. [CrossRef] [PubMed]

139. Thestrup, H.N.; Hahn-Hägerdal, B. Xylitol formation and reduction equivalent generation during anaerobic xylose conversion with glucose as cosubstrate in recombinant Saccharomyces cerevisiae expressing the xyl1 gene. Appl. Environ. Microbiol. 1995, 61, 2043-2045. [PubMed]

140. Dahn, K.M.; Davis, B.P.; Pittman, P.E.; Kenealy, W.R.; Jeffries, T.W. Increased xylose reductase activity in the xylose-fermenting yeast Pichia stipitis by overexpression of XYL1. Appl. Biochem. Biotechnol. 1996, 57-58, 267-276. [CrossRef]

141. Kötter, P.; Amore, R.; Hollenberg, C.P.; Ciriacy, M. Isolation and characterization of the Pichia stipitis xylitol dehydrogenase gene, XYL2, and construction of a xylose-utilizing Saccharomyces cerevisiae transformant. Curr Genet. 1990, 18, 493-500. [CrossRef] [PubMed]

142. Amore, R.; Kötter, P.; Kuster, C.; Ciriacy, M.; Hollenberg, C.P. Cloning and expression in Saccharomyces cerevisiae of the NAD(P)H-dependent xylose reductase-encoding gene (XYL1) from the xylose-assimilating yeast Pichia stipitis. Gene 1991, 109, 89-97. [CrossRef]

143. Walfridsson, M.; Anderlund, M.; Bao, X.; Hahn-Hägerdal, B. Expression of different levels of enzymes from the Pichia stipitis XYL1 and XYL2 genes in Saccharomyces cerevisiae and its effects on product formation during xylose utilisation. Appl. Microbiol. Biotechnol. 1997, 48, 218-224. [CrossRef] [PubMed] 
144. Jin, Y.S.; Jeffries, T.W. Changing flux of xylose metabolites by altering expression of xylose reductase and xylitol dehydrogenase in recombinant Saccharomyces cerevisiae. Appl. Biochem. Biotechnol. 2003, 105-108, 277-285. [CrossRef]

145. Zong, H.; Zhang, C.; Zhuge, B.; Lu, X.; Fang, H.; Sun, J. Effects of xylitol dehydrogenase (XYL2) on xylose fermentation by engineered Candida glycerinogenes. Biotechnol. Appl. Biochem. 2017, 64, 590-599. [CrossRef] [PubMed]

146. Jo, J.H.; Park, Y.C.; Yong-Su Jin, Y.S.; Seo, J.H. Construction of efficient xylose-fermenting Saccharomyces cerevisiae through a synthetic isozyme system of xylose reductase from Scheffersomyces stipites. Bioresour. Technol. 2017, 241, 88-94. [CrossRef] [PubMed]

147. Leandro, M.J.; Gonçalves, P.; Spencer-Martins, I. Two glucose/xylose transporter genes from the yeast Candida intermedia: First molecular characterization of a yeast xylose-H+ symporter. Biochem. J. 2006, 395, 543-549. [CrossRef] [PubMed]

148. Runquist, D.; Fonseca, C.; Rådstrom, P.; Spencer-Martins, I.; Hahn-Hägerdal, B. Expression of the Gxf1 transporter from Candida intermedia improves fermentation performance in recombinant xylose-utilizing Saccharomyces cerevisiae. Appl. Microbiol. Biotechnol. 2009, 82, 123-130. [CrossRef] [PubMed]

149. Katahira, S.; Ito, M.; Takema, H.; Fujita, Y.; Tanino, T.; Tanak, T.; Fukuda, H.; Kondo, A. Improvement of ethanol productivity during xylose and glucose co-fermentation by xylose-assimilating $\mathrm{S}$. cerevisiae via expression of glucose transporter Sut1. Enzyme Microb. Technol. 2008, 43, 115-119. [CrossRef]

150. Boles, E.; Hollenberg, C.P. The molecular genetics of hexose transport in yeasts. FEMS Microbiol. Rev. 1997, 21, 85-111. [CrossRef] [PubMed]

151. Maier, A.; Volker, B.; Boles, E.; Fuhrmann, G.F. Characterisation of glucose transport in Saccharomyces cerevisiae with plasma membrane vesicles (countertransport) and intact cells (initial uptake) with single Hxt1, Hxt2, Hxt3, Hxt4, Hxt6, Hxt7 or Gal2 transporters. FEMS Yeast Res. 2002, 2, 539-550. [PubMed]

152. Meinander, N.Q.; Hahn-Hägerdal, B. Influence of co-substrate concentration on xylose conversion by recombinant, XYL1expressing Saccharomyces cerevisiae: A comparison of different sugars and ethanol as cosubstrates. Appl. Environ. Microbiol. 1997, 63, 1959-1964. [PubMed]

153. Lee, W.J.; Kim, M.D.; Ryu, Y.W.; Bisson, L.F.; Seo, J.H. Kinetic studies on glucose and xylose transport in Saccharomyces cerevisiae. Appl. Microbiol. Biotechnol. 2002, 60, 186-191. [PubMed]

154. Buziol, S.; Becker, J.; Baumeister, A.; Jung, S.; Mauch, K.; Reuss, M.; Boles, E. Determination of in vivo kinetics of the starvation-induced Hxt5 glucose transporter of Saccharomyces cerevisiae. FEMS Yeast Res. 2002, 2, 283-291. [PubMed]

155. Jin, Y.S. Metabolic Engineering of Xylose Fermentation in Saccharomyces Cerevisiae. PhD Thesis, University of Wisconsin, Madison, WI, USA, 2002.

156. Hamacher, T.; Becker, J.; Gardonyi, M.; Hahn-Hägerdal, B.; Boles, E. Characterization of the xylose-transporting properties of yeast hexose transporters and their influence on xylose utilization. Microbiology 2002, 148, 2783-2788. [CrossRef] [PubMed]

157. Colabardini, C.A.; Ries, L.N.A. Brown Functional characterization of a xylose transporter in Aspergillus nidulans. Biotechnol. Biofuels 2014, 7, 46-64. [CrossRef] [PubMed]

158. Rintala, E.; Wiebe, M.G.; Tamminen, A.; Ruohonen, L.; Penttila, M. Transcription of hexose transporters of Saccharomyces cerevisiae is affected by change in oxygen provision. BMC Microbiol. 2008, 8, 53. [CrossRef] [PubMed]

159. Bertilsson, M.; Andersson, J.; Liden, G. Modeling simultaneous glucose and xylose uptake in Saccharomyces cerevisiae from kinetics and gene expression of sugar transporters. Bioprocess Biosyst. Eng. 2008, 31, 369-377. [CrossRef] [PubMed]

160. Van Maris, A.J.; Winkler, A.A.; Kuyper, M.; de Laat, W.T.; Van Dijken, J.P.; Pronk, J.T. Development of efficient xylose fermentation in Saccharomyces cerevisiae: Xylose isomerase as a key component. Adv. Biochem. Eng. Biotechnol. 2007, 108, 179-204. [PubMed]

161. Nijland, J.G.; Shin, H.Y.; Boender, L.G.M.; de Waal, P.P.; Klaassen, P.; Driessen, A.J.M. Improved xylose metabolism by a CYC8 mutant of Saccharomyces cerevisiae. Appl. Environ. Microbiol. 2017, 83, 95-117. [CrossRef] [PubMed]

162. Chang, S.F.; Ho, N.W. Cloning the yeast xylulokinase gene for the improvement of xylose fermentation. Appl. Biochem. Biotechnol. 1988, 17, 313-318. [CrossRef] [PubMed] 
163. Deng, X.X.; Ho, N.W. Xylulokinase activity in various yeasts including Saccharomyces cerevisiae containing the cloned xylulokinase gene. Appl. Biochem. Biotechnol. 1990, 24-25, 193-199. [CrossRef]

164. Ho, N.W.; Tsao, G.T. Recombinant Yeasts for Effective Fermentation of Glucose and Xylose. US Patent 5789210, 8 November 1993.

165. Rodriguez-Pena, J.M.; Cid, V.J.; Arroyo, J.; Nombela, C. The YGR194c (XKS1) gene encodes the xylulokinase from the budding yeast Saccharomyces cerevisiae. FEMS Microbiol. Lett. 1998, 162, 155-160. [CrossRef]

166. Eliasson, A.; Christensson, C.; Wahlbom, F.C.; Hahn-hägerdal, B. Anaerobic xylose fermentation by recombinant Saccharomyces cerevisia carrying XYL1, XYL2, and XKS1 in mineral medium chemostat cultures. Appl. Environ. Microbiol. 2000, 66, 3381-3386. [CrossRef] [PubMed]

167. Krishna, S.H.; Chowdary, G.V.; Reddy, D.S.; Ayyanna, C. Simultaneous saccharification and fermentation of pretreated Antigonum leptopus (Linn) leaves to ethanol. J. Chem. Technol. Biotechnol. 1999, 74, 1055-1060. [CrossRef]

168. Jin, Y.S.; Ni, H.; Laplaza, J.M.; Jeffries, T.W. Optimal growth and ethanol production from xylose by recombinant Saccharomyces cerevisiae require moderate D-xylulokinase activity. Appl. Environ. Microbiol. 2003, 69, 495-503. [CrossRef] [PubMed]

169. Richard, P.; Toivari, M.H.; Penttilä, M. The role of xylulokinase in Saccharomyces cerevisiae xylulose catabolism. FEMS Microbiol. Lett. 2000, 190, 39-43. [CrossRef] [PubMed]

170. Johansson, B.; Christensson, C.; Hobley, T.; Hahn-Hägerdal, B. Xylulokinase overexpression in two strains of Saccharomyces cerevisiae also expressing xylose reductase and xylitol dehydrogenase and its effect on fermentation of xylose and lignocellulosic hydrolysate. Appl. Environ. Microbiol. 2001, 67, 4249-4255. [CrossRef] [PubMed]

171. Toivari, M.H.; Aristidou, A.; Ruohonen, L.; Penttilä, M. Conversion of xylose to ethanol by recombinant Saccharomyces cerevisiae: Importance of xylulokinase (XKS1) and oxygen availability. Metab. Eng. 2001, 3, 236-249. [CrossRef] [PubMed]

172. Jin, Y.S.; Jones, S.; Shi, N.Q.; Jeffries, T.W. Molecular cloning of XYL3 (D-xylulokinase) from Pichia stipitis and characterization of its physiological function. Appl. Environ. Microbiol. 2002, 68, 1232-1239. [CrossRef] [PubMed]

173. Sunna, A.; Antranikian, G. Xylanolytic Enzymes from Fungi and Bacteria. Crit. Rev. Biotechnol. 1997, 17, 39-67. [CrossRef] [PubMed]

174. Morosoli, R.; Zalce, E.; Durand, S. Secretion of a Cryptococcus albidus xylanase in Pichia stipitis resulting in a xylan fermenting transformant. Curr. Genet. 1993, 24, 94-99. [CrossRef] [PubMed]

175. Den Haan, R.; Van Zyl, W.H. Differential expression of the Trichoderma reesei $\beta$-xylanase II (xyn2) gene in the xylose-fermenting yeast Pichia stipitis. Appl. Microbiol. Biotechnol. 2001, 57, 5215-5227.

176. Basaran, P.; Basaran, N.; Hang, Y.D. Isolation and characterization of Pichia stipitismutants with enhanced xylanase activity. World J. Microbiol. Biotechnol. 2000, 16, 545-550. [CrossRef]

177. Görgens, J.F.; Passoth, V.; van Zyl, W.H.; Knoetze, J.H.; Hahn-Hagerdahl, B. Amino acid supplementation, controlled oxygen limitation and sequential double induction improve heterologous xylanase production by Pichia stipitis. FEMS Yeast Res. 2005, 5, 677-683. [CrossRef] [PubMed]

178. La Grange, D.C.; Pretorius, I.S.; Claeyssens, M.; Van Zyl, W.H. Degradation of xylan to D-xylose by recombinant Saccharomyces cerevisiae coexpressing the Aspergillus niger $\beta$-xylosidase $(x \operatorname{lnD})$ and the Trichoderma reesei xylanase II (xyn2) genes. Appl. Environ. Microbiol. 2001, 67, 5512-5519. [CrossRef] [PubMed]

179. Görgens, J.F.; Pianas, J.; van, W.H.; Knoetze, J.H.; Hahn-Hägerdal, B. Comparison of three expression systems for heterologous xylanase production by S. cerevisiae in defined medium. Yeast 2004, 21, 1205-1217. [PubMed]

180. Jampala, P.; Tadikamalla, S.; Preethi, M.; Ramanujam, S.; Uppuluri, K.B. Concurrent production of cellulase and xylanase from Trichoderma reesei NCIM 1186: Enhancement of production by desirability-based multi-objective method. Biotech 2017, 7, 14. [CrossRef] [PubMed]

181. Du Preez, J.C.; Prior, B.A.; Monteiro, A.M.T. The effect of aeration on xylose fermentation by Candida shehatae and Pachysolen tannophilus-A comparative study. Appl. Microbiol. Biotechnol. 1984, 19, 261-266.

182. Sanchez, S.; Bravo, V.; Castro, E.; Moya, A.J.; Camacho, F. Comparative study of the fermentation of D-glucose/D-xylose mixtures with Pachysolen tannophilus and Candida shehatae. Bioprocess Eng. 1999, 21, 525-532. [CrossRef] 
183. Vandeska, E.; Amartey, S.; Kuzmanova, S.; Jeffries, T.W. Fed-batch culture for xylitol production by Candida boidinii. Proc. Biochem. 1996, 31, 265-270. [CrossRef]

184. Winkelhausen, E.; Pittman, P.; Kuzmanova, S.; Jeffries, T.W. Xylitol formation byCandida boidinii in oxygen limited chemostat culture. Biotechnol. Lett. 1996, 18, 753-758. [CrossRef]

185. Rodrigues, D.C.; Da Silva, S.S.; Almeida, E.S.J.B.; Vitolo, M. Xylose reductase activity of Candida guilliermondii during xylitol production by fed-batch fermentation: Selection of process variables. Appl. Biochem. Biotechnol. 2002, 98-100, 875-883. [CrossRef]

186. Sanchez, S.; Bravo, V.; Castro, E.; Moya, A.J.; Camacho, F. The fermentation of mixtures Of D-glucose and D-xylose by Candida shehatae, Pichia stipitis or Pachysolen tannophilusto produce ethanol. J. Chem. Technol. Biotechnol. 2002, 77, 641-648. [CrossRef]

187. Cho, J.Y.; Jeffries, T.W. Pichia stipitis genes for alcohol dehydrogenase with fermentative and respiratory functions. Appl. Environ. Microbiol. 1998, 64, 1350-1358. [PubMed]

188. Cho, J.Y.; Jeffries, T.W. Transcriptional control of ADH genes in the xylose-fermenting yeast Pichia stipitis. Appl. Environ. Microbiol. 1999, 65, 2363-2368. [PubMed]

189. Kim, Y.S.; Kim, S.Y.; Kim, J.H.; Kim, S.C. Xylitol production using recombinantSaccharomyces cerevisiae containing multiple xylose reductase genes at chromosomal delta-sequences. J. Biotechnol. 1999, 67, 159-171. [CrossRef]

190. Jeppsson, M.; Johansson, B.; Hahn-Hägerdal, B.; Gorwa-Grauslund, M.F. Reduced oxidative pentose phosphate pathway flux in recombinant xylose-utilizing Saccharomyces cerevisiae strains improves the ethanol yield from xylose. Appl. Environ. Microbiol. 2002, 68, 1604-1609. [CrossRef] [PubMed]

191. Richard, P.; Verho, R.; Putkonen, M.; Londesborough, J.; Penttilä, M. Production of ethanol from L-arabinose by Saccharomyces cerevisiae containing a fungal L-arabinose pathway. FEMS Yeast Res. 2003, 3, 185-189. [CrossRef]

192. Nissen, T.L.; Schulze, U.; Nielsen, J.; Villadsen, J. Flux distributions in anaerobic, glucose-limited continuous cultures of Saccharomyces cerevisiae. Microbiology 1997, 143, 203-218. [CrossRef] [PubMed]

193. Rizzi, M.; Erlemann, P.; Buithanh, N.A.; Dellweg, H. Xylose fermentation by yeasts 4 . Purification and kinetic studies of xylose reductase from Pichia stipitis. Appl. Microbiol. Biotechnol. 1988, 29, 148-154.

194. Michal, G. Biochemical Pathways: An Atlas of Biochemistry and Molecular Biology; Wiley: New York, NY, USA, 1999; pp. 189-200.

195. Anushree, K.; Anand, G. Xylitol production by Saccharomyces cerevisiae overexpressing different xylose reductases using non-detoxified hemicellulosic hydrolysate of corncob. Biotech 2016, 6, 127. [CrossRef]

196. Park, N.H.; Yoshida, S.; Takakashi, A.; Kawabata, Y.; Sun, H.J.; Kusakabe, I. A new method for the preparation of crystalline L-arabinose from arabinoxylan by enzymatic hydrolysis and selective fermentation with yeast. Biotechnol. Lett. 2001, 23, 411-416. [CrossRef]

197. Dien, B.S.; Kurtzman, C.P.; Saha, B.C.; Bothast, R.J. Screening for L-arabinose fermenting yeasts. Appl. Biochem. Biotechnol. 1996, 57-58, 233-242. [CrossRef]

198. Shi, N.Q.; Prahl, K.; Hendrick, J.; Cruz, J.; Lu, P.; Cho, J.Y.; Jones, S.; Jeffries, T. Characterization and complementation of a Pichia stipitis mutant unable to grow on D-xylose or L-arabinose. Appl. Biochem. Biotechnol. 2000, 848, 201-216. [CrossRef]

199. Witteveen, C.F.B.; Busink, R.; Van de Vondervoort, P.; Dijkema, C.; Swart, K.; Visser, J. L-Arabinose and D-Xylose Catabolism in Aspergillus niger. J. Gen. Microbiol. 1989, 135, 2163-2171. [CrossRef]

200. Rees, D.A. Polysaccharide Shapes. Outline Studies of Biology; Wiley: New York, NY, USA, 1977; pp. 62-73.

201. Lucas, C.; Van Uden, N. Transport of hemicellulose monomers in the xylose-fermenting yeast Candida shehatae. Appl. Microbiol. Biotechnol. 1986, 23, 491-495. [CrossRef]

202. Hallborn, J.; Walfridsson, M.; Penttilä, M.; Keranen, S.; Hahn-Hägerdal, B. A short-chain dehydrogenase gene from Pichia stipitis having D-arabinitol dehydrogenase activity. Yeast 1995, 11, 839-847. [CrossRef] [PubMed]

203. Richard, P.; Londesborough, J.; Putkonen, M.; Kalkkinen, N.; Penttilä, M. Cloning and expression of a fungal L-arabinitol 4-dehydrogenase gene. J. Biol. Chem. 2001, 276, 40631-40637. [CrossRef] [PubMed]

204. Richard, P.; Putkonen, M.; Väänänen, R.; Londesborough, J.; Penttilä, M. The missing link in the fungal L-arabinose catabolic pathway, identification of the L-xylulose reductase gene. Biochemistry 2002, 41, 6432-6643. [CrossRef] [PubMed] 
205. Becker, J.; Boles, E. A modified Saccharomyces cerevisiae strain that consumes L-arabinose and produces ethanol. Appl. Environ. Microbiol. 2003, 69, 4144-4150. [CrossRef] [PubMed]

206. Wang, C.; Zhao, J.; Qiu, C.; Wang, S.; Shen, Y.; Du, B.; Ding, Y.; Bao, X. Coutilization of D-Glucose, D-Xylose, and L-Arabinose in Saccharomyces cerevisiae by Coexpressing the Metabolic Pathways and Evolutionary Engineering. Biomed. Res. Int. 2017, 1-8. [CrossRef] [PubMed]

207. Zabed, H.; Faruq, G.; Sahu, J.N.; Azirun, M.S.; Hashim, R.; Boyce, A.N. Bioethanol production from fermentable sugar juice. Sci. World J. 2014, 8, 1-11. [CrossRef] [PubMed]

208. Field, S.; Ryden, P.; Wilson, D.; James, S.; Roberts, I.; Richardson, D.; Waldron, K.W.; Clarke, T.A. Identification of furfural resistant strains of Saccharomyces cerevisiae and Saccharomyces paradoxus from a collection of environmental and industrial isolates. Biotechnol. Biofuels 2015, 8, 33. [CrossRef] [PubMed]

209. MarelneCot, M.; Loret, M.O.; Francois, J. Physiological behavior of Saccharomyces cerevisiaein aerated fed-batch fermentation for high level production of bioethanol. FEMS Yeast Res. 2007, 7, 22-32.

210. Liu, R.; Shen, F. Impacts of main factors on bioethanol fermentation from stalk juice of sweet sorghum by immobilized Saccharomyces cerevisiae (CICC 1308). Bioresour. Technol. 2008, 99, 847-854. [CrossRef] [PubMed]

211. Phisalaphong, M.; Srirattana, N.; Tanthapanichakoon, W. Mathematical modeling to investigate temperature effect on kinetic parameters of ethanol fermentation. J. Biochem. Eng. 2006, 28, 36-43. [CrossRef]

212. Lin, Y.; Zhang, W.; Li, C.; Sakakibara, K.; Tanaka, S.; Kong, H. Factors affecting ethanol fermentation using Saccharomy cescerevisiae BY4742. Biomass Bioenergy 2012, 47, 395-401. [CrossRef]

213. Staniszewski, M.; Kujawski, W.; Lewandowska, M. Ethanol production from whey in bioreactor with co-immobilized enzyme and yeast cells followed by pervaporative recovery of product-Kinetic model predictions. J. Food Eng. 2007, 82, 618-625. [CrossRef]

214. Laopaiboon, L.; Thanonkeo, P.; Jaisil, P.; Laopaiboon, P. Ethanol production from sweet sorghum juice in batch and fed-batch fermentations by Saccharomyces cerevisiae. World J. Microbiol. Biotechnol. 2007, 23, 1497-1501. [CrossRef]

215. Palmqvist, E.; Hahn-Hägerdal, B. Fermentation of lignocellulosic hydrolysates. II: Inhibitors and mechanisms of inhibition. Bioresour. Technol. 2000, 74, 25-33.

216. Larsson, S.; Quintana-Sáinz, A.; Reimann, A.; Nilvebrant, N.-O.; Jönsson, L. Influence of lignocellulose-derived aromatic compounds on oxygen-limited growth and ethanolic fermentation by Saccharomyces cerevisiae. In Twenty-First Symposium on Biotechnology for Fuels and Chemicals; Finkelstein, M., Davison, B., Eds.; Humana Press: Fort Collins, CO, USA, 2000; pp. 617-632. 